

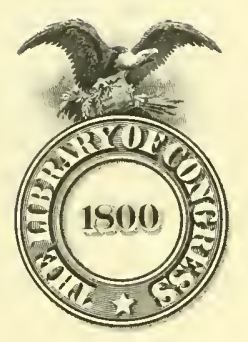

lliss $5 \mathrm{H} 364$

linok ULo

1897 

, 



\section{A REPORT}

ON THK

\section{SEA-OTTER BANKS OF ALASKA.}

RANGE AND HABITS OF THE SEA OTTER-ITS DECREASE UNDER AMERICAN RULE, AND SOME OF THE CAUSES-IMPORTANCE OF THE SEA OTTER TO THE NATIVES OF ALASKA INHABITING THE ALEUTIAN ISLANDSPROPOSED REGULATIONS FOR 1898.

BY

C. L. HOOPER, Captain R. C. S., COMMANDING BERING SEA PATROL FLEET, 1897.

WASHINGTON: GOVERNMENT PRINTING OFFICE. 1897. 



\section{A REPORT}

ON THE

\section{SEA-OTTER BAXKS OF ALASKA.}

RANGE AND HABITS OF THE SEA OTTER-ITS DECREASE UNDER AIIERICAN RTLE, AND SOIE OP THE CATSES-IJPORTANCE OF THE SEA OTTER TO RHE NATIVES OF ALASKA INHABITING THE ALETTIAN ISLANISPROPOSED REGULATIONS FOR 1898.

BY

C. T. HoOPER. Captain, T. C. S., COMMANDING BEIING SEA PATROL FLEET, 1897.

WASHINGTON: GOVERNMENT PRINTING NFHCL。 1897. 


$$
5+3 v^{5}
$$

\section{Treasury Departmext.}

Document No. 1977.

Ofice of Secretary, Division of Rerenue Cutter Serrico.

stín

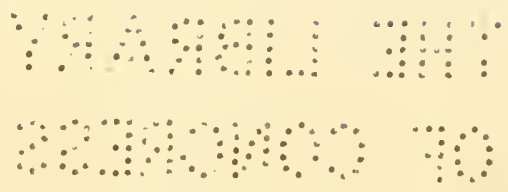




\title{
REPORT ON THE SEA-OTTER BANKS OF ALASKA.
}

\author{
HeAd-quarters Bering Sea Fleet, \\ UnALASKA, Alaska, \\ September 15, $189 \%$.
}

SIR: I have the hour to submit, for your information and considera. tion, the following rejort ou the Sea-Otter Banks of Alaska:

EARLY SEA-OTTER HUNTING.

When the Russians first visited Alaska, its waters abounded in sea otter, and the early voyagers reaped a rich havest, hunting them without restraint. As a result, after more than fifty years, toward the close of the eighteenth century, a marked decrease was noticeable.

The otter, which at the time of the discovery of the Pribilof Islands, 1756, were said to have "swarmed the shores of St. George," had almost entirely disappeared, and at many other places there had been a decided falling off in their numbers.

\section{RUSSIAN-AMERICAN COMPANY.}

About the close of the century the Russian-American Company was organized and duly chartered by the Czar for a term of twenty years. This company, which in 1820 had its charter renewerl, had been granted new privileges, and was practically in control of the Territory, and exercised, to some extent, a supervision over the hunters and placed restrictions on the unmber of sea otter to be taken. The demands of the market were considered and the catch apportioned to the different districts with reference to the number of hunters, etc. The natives were held strictly to the number aliotted, and any otter killed in excess were carried over until the next year. They also laid down certain rules for the hunters to avoid disturbing the otter, lest they should be driven away.

It that time the otter hauled ont upon the land to feed on the sea mrehins and other shellish exposed at low water, to sleep and rest, and give birth to their young, and were taken in nets and killed by clubbing. The females were spared, and one of the first lessons taught the young hunter after he had learned to manage the kyak and to throw the spear was how to distinguish the female from the male animal in the water, by the color and shape of its head and neck, which, unlike the fur seal, differ sufficiently to clearly mark the sexes. When hunting upon the 
shores, care was taken by the lunters to avoid any noise or disturiance, or leaving any mak or sign by which their presence might become known to the otter, which are exceedingly timid and suspieions and easily driven away from a locality if disturbed. The sea otter is very unlike that most stupid of all animals, the fur seal, which, commencing as a yearling, makes periodical trips to the killing grounds with the "(lrive," crawling over the bones of many generations of its ancestors, and nearly smothered in the high grass fertilized by their deraying bollies, presents itself for inspection year after year until of suitable age to be killerl, when, surromed by its dear companions, it takes the desired position and cranes its neek forwarl to meet the deadly club, which, with one blow on its tender skull, makes this trip to the killing gronud its last.

Thoots with iron nails were prohibited, and tires were built away from the hauling grounds and lighted only when the wind was from the sea to carry the smoke inlaud. No guns were used, only the noiselesis but equally deally spear.

DECREASE OF SHA OTTER.

In spite of all the precantions taken the sea otter appear to have decreased from year to year, and in some parts, notably the liribilof Islands, to have entirely disappenred before Alaska came under the American flag. Atter the trausfer, althongl the same rigid rules conld not be entoreer, the effects of them were felt for some years. From habit many of the matire hunters contimed to slare the female, but gralnally all precantions came to be ignored. Hunting seloomers came yearly to the otter bauks; cod fisheries were established in the immediate vioinity of them, and the offal lined the shores and filled the Watel. One of the best otter gromuls in Alaska, the Sammaliecfis, is said to liave been greatly injured by the cod fisheries establisher there.

()n account of the vast extent of country and the limited force at its commaud, the Government has not enforced the law prohibiting white men from killing fu-bearing animals in Alaska, and the sea ot ter, being the most valuable. lass receiver its full share of attention. Being ('onstantly hausser, chubbed and shot on shore, cansht in nets by white men, thein hanling arounds made minlabitable by the campl fines of the hunters and defiled lor fisheries and the decaying bodies of their slanglitered companions, the sea otter of the Alentian Islands has not only decreased in numbers, but has actually changed its habits. It mo longer comes ont "pon the land to feed. rest, or give birth to its yomms. A Hoating raft of lielp server as its only resting place, and bankis of 30 finthoms of water are its feeding groumls. Even there it is lumtend and halassed by hunting schooners from March mutil Angust. IIaving besul diven from the shore it is being exterminated on the sea by a lleet of hunting schooners, and the native lunters of the Aleutian Islands 
are being deprived of their chief means of subsistence. In addition to its change of habits and decrease in numbers, the range of the otter is very much reduced.

The otter grounds west of Unimak Pass are practieally abandoned. On some banks stray individuals are still taken at long intervals, while on others, not an otter has been taken during the last decale.

No reliable record of the cateh of sea otter prior to 1873 is obtainable and the record since that date is only approximate, ineluding those only that were bought by the Alaska Commereial Company, which were, however, a majority of all taken in these waters in actual numbers, and the change from year to year may be taken as proportionate to the changes which took place in the entire herd.

The accompranying tabular statement, for which I am indebted to the courtesy of the Alaska Commereial Company, shows the number of otter purehased by that company from 1873 to 1897 , both inclusive. In 1883 the North American Fur and Trading Company, which prior to that time had been trarling in furs, with headquarter's at Unalaska, sold ont its interests to the Alaska Commereial Company, and with them its stock of sea otter purehased that year, 466 in all. Supposing, in the absence of a better guide, that this number represents a fair average of yearly purehase of sea otter by the North American Fur and Trading Company for the ten years from 1873 to 188:3, we ean increase the yearly totals that amonnt. This does not include otter taken by sehooners aud not sold to the companies named.

SEA-OTTER BANKS.

The sea-otter grounds under consideration, for convenience sake, may be divided into distriets, as follows: Beginning at the extreme west, Attu, Atka, Umnak, Unalaska, Akutan, Sannak, Morzhovoi, Belkofski, Unga, and Kadiak.

ATTU.

The Attu grounds included Attu and Agattu, and were hunted by the Attu natives with kyak and spear. The other island named did not contain permanent inhabitants, but hunting parties crossed over from Attu in large skin boats during the offshore hunting season, from June to August, inelusive. The stormy condition of the sea prevented them venturing far from the shore in their frail boats at other seasons. The Attn otter grounds were on the south or Paeific side of the islands, and extended not more than 6 miles from the shore. Otter have almost entirely disappeared from these gronuds. Since 1882 only an oecasional one has been taken, althongh periodic hunting trips are still made. A native bunting party in the American sehooner Challenge in July, 1896, cruised over these grounds for eighteen days, with fine weather, without seeing one sea otter. 


\section{ATKA.}

The Atka grounds extend from and include Buldir Island on the west to Four Monntains on the east. This ground is elainerl and hunted by the Atka natives, who live at Nazan Bay, on the east end of the island, the only permanent settlement between Attu and Umnak since the abandoument, mayy years ago, of Korovin, a small settlement on the north side of the same island.

The conditions of native hunting on the Atka grounds were almost identical with those at Attu. The manner of hunting, distance from the shore, duration of the offshore hunting season, means of getting from island to island, the use of the kyak and spear, and all smaller details were the same. This was a large district and the otter banks far apart, and the difficulties and dangers to be met and overeome in going from one to the other in open skin boats ean only be appreciated by one who has experienced the dangerous tide races and overfalls that are to be encountered there, even in moderate weather, which try the seagoing qualities of small vessels. In many parts of this district the sea otter is entirely extinct. None have been taken from the Buldir Island banks since 1874. Oceasional otter are found in what is known loeally as Shut in Strait (Tanega Pass). Kiska and Amehitka, favorite hunting gronnds of former times, are eutirely abandoned; so also Seguam, Yunaska, and Amukta and the islands of Four Mountains.

UMNAK.

The sea-otter grounds of the Umnak district were eonfined to the bauks adjacent to this one island. Like those of Attu and Atka, the Umnak banks were on the Paeifie side of the island, bnt extended somewhat farther off shore. These banks were hnnted by the inhabitants of Nikolski, the only permanent settlement on the island, but are now entirely abandoned. For a number of years, owing to the great decrease of otter on the Ummak grounds, the people were very poor and deeply in debt, their only ineome being the few foxes they were able to eatch, seareely enough to supply them with tea and sugar. For the past four years they have been taken to the Kadiak banks in the schooner Everett Hays, of Unalaska, and have done fairly well, being able to furnish themselves and families with the necessaries of life, besides paying off a portion of their debts.

\section{UNALASKA.}

The hunting ground of the Unalaska division is on the sonth or Pacifie side of the island, and extends its entire length. It is hunted by the natives of each of the five settlements on the island-Biorka, Cheruofski, Kashega, Makushin, and Unalaska (Iliuliuk).

The men use both gun and spear in hunting otter, and extend their hunting farther off shore; otherwise the conditions are the same as at 
the other divisions referred to. But few otter have been found on the Unalaska banks for several years, by far the larger part of those credited to Unalaska in the tabulated statement having been taken by Unalaska hunters on the Kadiak grounds.

\section{AKUTAN.}

The Akutan division includes the banks south of Akutan, Avatanak, and Tigalda. These were claimed and hunted by the natives of Akutan Harbor, the only permanent habitation in this group. Here, also, the hunters used both gun and spear. The otter of this division are practically extinct. For the past ten years the anuual eatch has not exceeded 3, and more frequently it is only 1.

\section{SANNAK.}

The Sannak district, which includes the reef and banks lying off the Sannak Islands, was claimed and hunted by the Belkofski natives and a few living on Sannak. For many years hunting parties from Akutan and Unalaska Island, and even from the divisions farther west, have been carried in schooners each year to these banks and taken away again at the end of the hunting season. Some parties have been left there during the winter, comfortable houses having been built for their accommodation. The otter are now nearly extinct on the Sannak grounds, the greater part of those credited to this district since 1890 having beeu taken on the Kadiak grounds.

Vessels fitted out for hunting on the Saunak grounds, failing to find otter there, extend their cruising to the Kadiak grounds, but keep no separate account of the catch, and it is all credited to the ground for which the vessel sailed originally. The few taken from this ground are taken by schooners well off shore.

\section{MORZHOVOI.}

This district was hunted by the inhabitants of the settlement of that name in Isanotski Strait or False Pass. The hnnting ground embraces the banks and reefs in the vicinity of the pass on the Pacific side, the pass itself in which during Russian times many thousands were taken, and the banks in Bering Sea between Cape Lapin, Unimak Island, on the soutliwest, and Amak Island on the northeast. For many years the Morzhovoi natives have used both gun and spear. This ground is neariy hunted out, and a large part of the skins eredited to it during the past ten years were taken on the Kadiak grounds by Morzhovoi hunters.

\section{BELKOFSKI.}

This district includes Belkofski and Wosnessenski and the outlying reefs and banks. The district was hunted by natives of both islands, the gun and spear being used. This was one of the richest districts, 
and prior to $1 S S 8$ prodneed annually mpward of 700 skins. Since that date the number has fallen off gradnally until, in 1896 , but 16 were taken by the natives of both settlements.

UNGA.

The Unga distriet includes all the banks and reefs lying off the outer Shumagin Islands. These grounds were hunted by the inhabitants of Delarof Harbor, Unga Island; Korovin, a small settlement on the island of that name, and simeonofski. They used guns and spears. This district formerly produced from 300 to 400 otter Gach year. In 1896 but 22 were taken.

KADIAK.

The Kadiak district inclutes the banks in the vicinity of the island, also Cook Inlet and Shelikof Strait. In the latter places but few remain.

\section{PRESENT OTTER GROUNDS.}

A majority of all the sea otter taken at the present day thronghont the Aleutian Islands are taken on the banks to the southwest of Kadiak. The banks are bounded on the northwest by the Alaska Peninsula, on the northeast by Kadiak Islands, southeast by the Trinity Islands and Chirikof, and on the southwest by the Semedi Islauds. It will be seen that the decrease of the otter has been general and is not eoufined to any particular locality. Neither does it appear that any particular style of huntiug is more destructive than the rest.

In the western districts, Attu and Atka, where only the spear was used, the decrease has been quite as marked as in the eastern districts, where the gum has been used almost exchsively. The gm, while not more destructive than the spear, is perhaps more wasteful, as by its use some are probably wounded but escape capture and die, while of those struck by the spear but few if any are lost.

\section{NETTING SEA OTTER.}

Netting is also a wasteful method of taking otter. Unless the animals canght are taken out of the net within a few hours after death, the carcass is attacked by millions of minute animals (small amphipod crustaceans) that infest these water's, and in a little while the pelt is rendered worthless. Netting is done during the stormy weather. The net is stretched from the shore to a convenient ontlying rock. Cold, hard storms prevail, which freqnently prevent the nets being visited for diys at a time, aud in the past many valuable skins have been lost in this way. Netting is not general at the present time, but is practiced to some extent by white men who inhabit the small outer islands of the Sannak and Shumagin groups and at other points. 
IMPORTANCE OF THE SEA OTTER TO THE ALEUTS.

The sea otter has been, since the first advent of the Russians, the principal means of support of the natives of the Aleutian Islands. The decrease in the yearly catch has already bronght some of the settlements to a state of want, and if they are allowed to become exterminated, actual suffering and even starvation ean only be averted by Government aid. Properly protected aud reserved exchusively for the use of the natives, the otter, while it can probably never be bronght up, to its former numbers, can be preserved from extermination and will furnish a means of subsistence for these people for many years.

\section{WHITE HUNTERS.}

In former references to this subject I have urged upon the Government the justice of allowing the white men married to native women and actually settled within the Territory to take sea otter by means of the net. This necessity no longer exists. The opening of mines and eanneries in varions parts of Alaska will furnish employment for all such, and in time no donlt the natives in the vieinity may be made nseful in the same way; but a large majority of the latter are isolated, many hundreds of miles away, and in numbers far in excess of the present needs of the mines and canneries.

Inclosed and forming a part of this report is a statement of the number of natives at the different Alentian settlements at the present time, ohtained by actual count and from the records of the Greek Church, for which I am under obligation to the resident Russian priest, liev. A. Kedrofsky.

There are in all sixteen wative settlements, and an aggregate of 1,165 native inhabitants.

\section{RESOURCES OF 'THE ALEUTIAN ISLANDS.}

The resonrces of these islands may be stated as follows: Attn, in addition to an oceasional otter, produces a limited number of blue foxes, but they are inferior in quality to those taken on the Pribilof Islands, and do not bring so high a price. The catch is yearly getting smaller. Some of the islands in the Atka district still furnish a few fox skins of different varieties. From Kanaga a few red and cross foxes are obtained. Adakh formerly produced many silver foxes, but has only a very few left. Great Sitchin Island produces a few red foxes only. Atka has only a few blue foxes of the same grade as those canght at Attu. Aulia has silver foxes, but they are almost extinct, only an occasional one being taken. Umnak and Unalaska disticts produce a few red and cross foxes and an oceasional silver fox. The islands in the Akutan district also produce red and cross foxes and an occasional silver fox. 


\section{ALASKA COMIERCIAL COMPANY.}

From the organization of the Alaska Commereial Company in 1869 to the present time a large part of the furs taken by the Aleut hunters were purchased by its agents, stores being maintained for the pirpose of trading at each of the native settlements. Owing to the falling off in the yield of furs many of these trading stations have been conducted at a loss for several years, and to avoid a continuation of these losses are being abandoned. In a few cases the station agents, men who are married to native women, and who, if not hunters themselves, acconpany the native hunting parties, have bought out the company's interest, and will, as a forlorn hope, still try to eke ont a living. At other places the stores are closed and all supplies taken away. A man named Dirks, for many years company's agent at Atka, purchased its interests at Atka and Attu. He also bought a small vessel, and so long as he can make it pay will keep a small suply of necessary stores at these places. Umnak and four of the five settlements on Unalaska Island-Chernofski, Kashega, Makushin, and Biorka-have been abandoned, as have Akutan, Sannak, Morzhovoi, Wosnessenski, and Belkofski.

\section{HUNTING FROM SCHOONERS.}

After the disappearance of the otter from the western hunting grounds it became necessary to transport hunting parties in schoouers to the Sannak and Kadiak grounds. At first the parties with their ontfits of bidarkas, guns, spears, tents, cooking utensils, etc., were taken by the vessel to some convenient point and landed, and hunted from the shore, living in tents. Of late years the hunting parties have remained on board the vessels and hunted from them. The vessels cruise over the hunting groumds, keeping a sharp lookont until otter are seen, when, if the weather is suitable, the bidarkas are put over and the chase begins.

The bidarkas keeping well together soon get the otter surrounded, tire it out, and captnre it without difficulty. Sea otter frequently travel in herds; sometimes 20 or 30 are seen at the same time. If the weather is favorable and the hunters work well together a fair percentage of all seen are taken.

Although all are hunting together, the otter belongs to the hunter who kills it, and strange as it may seem there is seldom a question as to ownership. If an otter is shot in such a way as to make it impossible to determine its rightful owner the matter is settled by giving the pelt to the chureh. In Russian times, when only the spears were used, each hunter had his mark, and the spear nearest the nose of the animal owned it. This was to induce the hunters to throw their spears at the head to avoid injuring the pelt.

In Angust the schooners return and a settlement is had. For its share of the work the schooner takes one-third of the otter caught, and the rest belong to the hunters. 
As stated, a majority of all pelts taken by the Alentian hunters are sold to the Alaska Commercial Company, whose method of dealing with the natives is particnlarly simple and fair. Immediately after the return of the hunting parties all the hunters meet, accompanied by the chief, and the furs are brought ont for inspection and appraisement by the comprany's agent. Those belonging to each hunter are examined separately, each fiur is appraised and the price offered is announced in Russian and repeated in Aleut in a tone loud and clear enongh for all to understand. Each hunter is furnished with a book in which the value of his catch is entered. From this is deducted the amount of his indebtedness to the company, aud the balance is paid in coin or placed to his credit as he may elect. After settling up, the work of buying a winter ontfit begins. With those who have money this is a simple cash transaction; gold is converted into silver and each article required is bouglit and paid for separately. To the hunter who has eaught nothing, and in consequence has no money, a winter's supply is given on credit. I am informed, however, that in fiture the Alaska Commercial Company will discontinue the eredit system and do only a cash business, to guard against loss. The system practiced has been so simple aud plain that even the Alent had no diffeulty in understanding it, and no differences arose.

After buying their winter outfit, the hunters and their purchases are taken on board the schooner in which they have been hunting and given free transportation to their homes.

CONCLUSIONS.

By the foregoing statements and annexed tables it will be seen: First, that the anuual catch of sea otter has been steadily and rapidly decreasing for the past ten years, the number killed yearly being apparently greater than the natural iucrease. Second, that the sea otter has not ouly decreased in number's, but that it has actually changed its habits and is no longer found on or near the shore; further, that the sea otter grounds are very much reduced in area. Third, that about 1,165 natives of the Aleutian Islands are almost wholly dependent upon the sea otter for the necessaries of life and will be left destitute if the animal is exterminated. Fourth, that on account of the decreased area of the hunting grounds and the disappearance of the otter from the western Aleutian Islands, a large number of the natives are isolated and can only reach the hunting grounds by the aid of schooners. Fifth, by the withdrawal of the Alaska Commercial Company's stores from the different settlements the natives are left dependent upon Unalaska for the necessaries of life, and communication between this and the other settlements can only be accomplished by vessel. The present generation lias not the art of building seagoing bidarras. Sea lion, from the skin of which the covering is made, have also decreased until there are only enough left to make the small bidarkas, and in any event the schooner 
is more comfortahle. safer, faster, and made use of in a jroper manner will not he detrimental to the sea otter herd. Sixth, it does not appear that the nse of firearms, although perialys more wasteful, is more destructive to the herd than spears. The banks of the Attu district. where the spear was used exclusively, were the first to be abandoned by the otter.

In the zueparation of regulations for the taking of sea otter these facts must be considered: It is not only necessary to preserve the otter, the most beantiful and valuable fur-bearing animal in the world, but to preserve it for the benefit of the natives who have been dependent upon it for more than a century, and who will be reduced to suffering and want without it.

In the preparation of regulations another point arises: Are the pres. ent sea-otter banks wholy within the territorial waters of the United States? If so, no international agreement to the regulations is necessary, as was the case with the fur seal. In the light of what knowledge I have upon the subject, I believe that the principal parts of the present sea-otter lnuting ground are wholly within the territorial waters of the United states.

As shown, the place where sea otter are hunted at present is to the sonthwest of Kadiak, on what is known as the Kadiak gromd. A reference to the accompanying ehart will show this body of water to be a large bay, a continnation of Shelikof Strait, entirely surrounded by land on three sides, and nearly so on the fourth, all of which land is United States territory. This bay has always been considered as territorial waters, and, so far as I know, no foreign vessel has ever hunted therein. In 1892 Hon. Warren Truitt, United States district jndge for the District of Alaska, decided that this was United States territorial waters and promptly condemned two sea-otter hunting vessels, the schooners St. Prul and Alexander, seized therein by the revenue steamer Corwin, for hunting sea otter with white innters, in violation of article 1956 , Revised Statutes. The view taken by Judge Truitt should be formally adopted by the Govermment of the United States.

Under almost precisely similar conditions, I am informed that the Canadian Government chims Hecate Strait, inside of Queen Charlotte Island, a much larger bay, as territorial water's, and American halibut fishermen are being warned away from there by the Doninion revenue eutter Quadru.

It this bay in which the otter are found derives a national character from the land by which it is surrounded, and the line representing the limit of United States jurisdiction passes 3 miles outsicle ol Kodiak, Trinity Islands, and Chirikof, suitable regulatious by the United States Government, properly enforced, will furnish ample protection for the sea otter, as not enough can be taken outside of these limits to encourage hunting to any extent. 
There are at the present time no British or other foreign vessels engaged in hunting sea otter in these waters, and it does not appear that any have done so in the past. Since this is a fact, and the recrease of sea otter is due to overkilling by our own people, it does not appear that there is any necessity for an international agreenent, or grounds npon which to ask it. If foreign vessels were not attracted in former times, they are not likely to be now that the sea-otter lied is rednced to barely one tenth its former numbers, and when not one of the American schoovers engaged in it is paying expenses.

If an international agreement shonld be deemed necessary, a fifteenmile limit, as shown on the chart transmitted herewith and forming a part of this report, wonld afford ample protectiou and shonld be adopted, althongh this is not recommended except as a last resort, and in that event an exception shonld be made in favor of the Alents hnuting from the shore in their native canoes (bidarkas), as is done in the fur-seal regulations, article 9, section 6, Bering Sea Award, in favor of the Indian hnnters farther sonth; otherwise one of the prime objects of the preservation of the sea otter will be defeated.

The article quoted permits the Indian bunters of the west coast of the Tnited States and British Columbia to hunt seals from the shore in their native canoes at all seasons, but mijustly and without apparent canse discriminates against the Alent and forbids him to hunt them at any time. To fully appreciate the injustice of this ruling, it must be kuown that the Aleuts nse the flesh of the fur seal as an article of food and prize it highly, while the Indians referred to do not eat it. The amonnt of seal meat thrown away by these Indian hmuters each year would go far toward furnishing the Aleuts with a much needed supply of fresh meat.

Herewith are appender a set of regulatious suggested for the government of sea-otter hunting for the season of 18 sts. As will be seen, these regulations are intended to preserve the remaining sea otter for the use of the Alent hunters and their families, in aceordance with the spirit of article 1950, Revised statutes. It is believed that this ean be attained only by prohibiting all lunnting from sehooners. There is no prohilition of the use of firearms suggested, for two reasous: Tirst. that it does not appear to be particularly injurions; second, becanse such a prohibition conld not be enfored without working great hardsinip upon the natives. Obvionsly, if forbidden to be used in linuting otter, the carrying of firearms by hunting parties must be prohibited. Todeprive these native hunting parties of the nse of guns to kill game while out on the long hunts of several months would indeed he a serious hardship, and conld not be consistently recomnended.

Ender mesent conditions the sea otter is becoming extinct, and, as many of the hunting schooners are manned by white hunters from san Francisco, the natives are receiving only a part of the benefit.

Under the proposed regulations the remaining otter will be preserred 
for the use of the natives, and they being compelled to hunt from the shore, only a limited number will be taken, and the herd will perhaps increase. Unless some action of this kind is taken, in a very few years a large portion of the Alentian Island natives must be taken eare of by the Government or starve.

If these regulations meet the approval of the Department, I respectfully recommend that they be adopted and promnlgated without delay, in order that the lumting schooners, some of which sail about February each year, may receive due notice.

Appended will also be fonnd tabular statements giving the number of sea otter taken in Alaskan waters, and census tables of the inhabitants of the islands, ete.

C. L. HOOPER,

Capt., R. C. S., Comdy. Bering sea Fleet.

Hon. LyMax J. GAGE,

Secretary of the Treasury. 


\section{APPENDIX.}

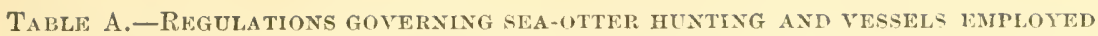
IN TRANSPORTING SEA-OTTER HUNTING PARTIES WITHIN THE TERRITORIAL WATERS OF Alaska For the YFAR 1898, UNDER AUTHority of ReVised Statutes.

\section{ARTICLE 1.}

No person shall be allowed to kill sea otter within the limits of Alaska 'Territory or the waters thereof, from or by the use of any boat or vessel other than the ordiaary.two-bateh skin-eoverel bidarka or the open Yakutat canoe.

\section{Article 2.}

Fnly sailing vessels and the birlarkas and the eanoes above descrilied may be employed in transporting sea-otter hunting parties to and from the hunting grounds, but no hunting from vessels shall be permitted.

\section{Article 3.}

Erery vessel employed in transporting sea-otter hunting parties shall have, in addition to the papers now required by law, a special order ur permit from the seeretary of the Treasury.

\section{ArTicle 1.}

The use of nets for the eapture of sea otter is prohibited.

\section{ARTICLE 5.}

It shall be the duty of officers of the linited States who may he stationed in the localities where sea otter are taken, or who may bave knowledle of any offense baving been committed, to take all proper neasures to enforce the penalties of the law.

\section{A RTIC1E 6.}

Foreign vessels of every description will be forluiden to hunt sea otter within the territorial waters of the Initerl States. Sneh prohiloition shall extenul to all waters lying between the peninsula of Alaska and a line drawn 3 miles to the sontheastward of a line conneeting the sontheastern heallands of the Island of Karliak, thenee extending to the southeastern hearlands of the Trinity Islands, of Chirikot, the Shumagin group, Sannak, and other islands of the Alentian gronp, to Attu, thence along the northern headlands of the Alentian Islands to the said peninsula of Alaski, as shown in the aecompanying chart, such waters thus inclosed being territorial waters of the United States.

\section{ARTICLE 7.}

Any master of a vessel or other person riolating any part of these regulatious shall le eonsirlered to have violated the provisions of suction 1956, Revised Statntes, hereinatter annexed, and will be liable to the penalty lescribed therein. (U. S. Rov. Stat., sec. 1956.) 
"No person slrall kill any otter, mink, marten, sable, or fur seal, or other furbraring animal within the limits of Alaska Territory, or in the waters thereof: amd ererg person guilty thereof shall, for each offense, be fined not less than two hundreal nor more than one thousand dollars, or imprisoned not more than six months, or lotb; and all vessels. their tackle, aplarel, furniture, and earyo, found engaged in riolation of this section shall be forfeited; hut the secretary of th. 'Theasury siall have power to antlorize the killing of any such mink, sable, or other fur-bearing animal, exeept fur sals, nuder suel reguhtions as he may preseribe; and it shall he the duty of the sec retary to prevent the killing of any fin seal, and to provide for the exantion of the provisums of this section until it is otherwise provieled by law; nor "Irall he grant any special privileges nuder this section."

\section{ARTICLL 8.}

The foregoing regulations are intended to apply only to the season of 1898.

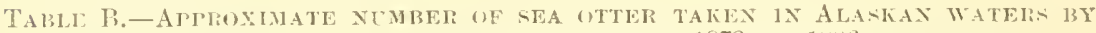

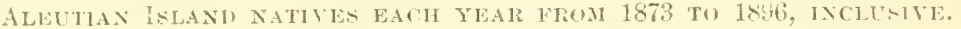

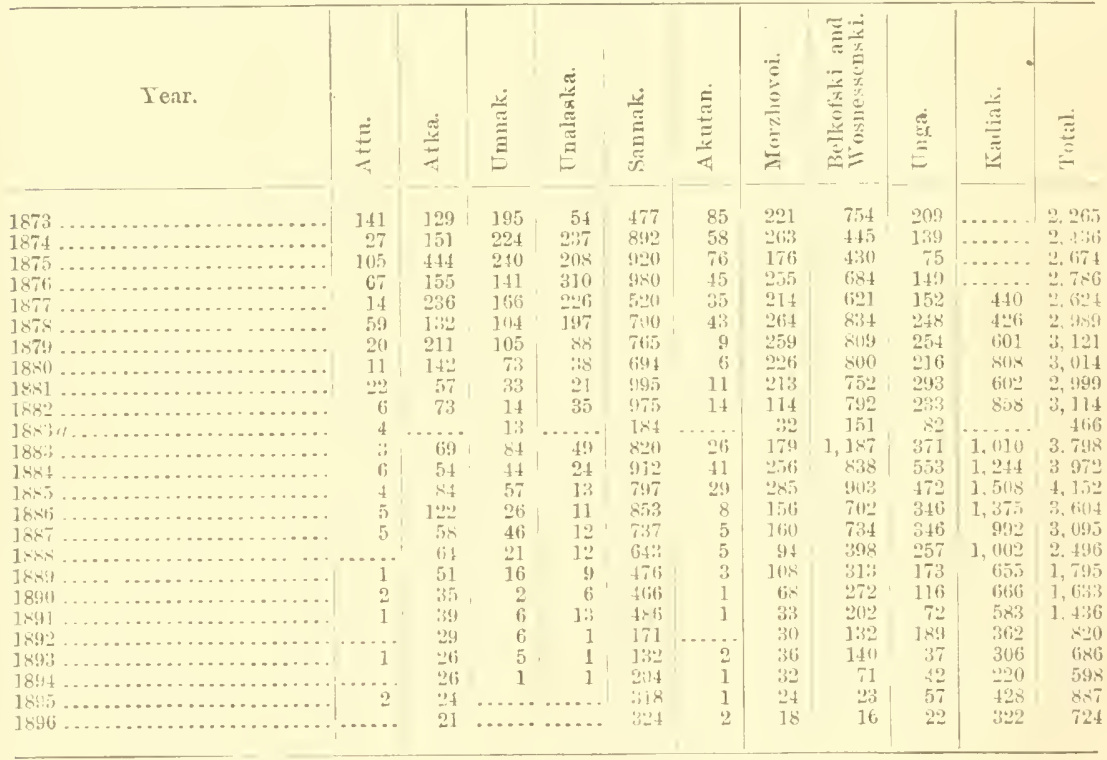

a l'urchased from North American Fur and Tradiug Conjany. 
Table C.-Censes statistics.

Census of natires on Unga Island dependent upon sea-otter huntiug.

\begin{tabular}{|c|c|c|c|c|}
\hline Name. & A ge. & Sex. & Where born. & Remarks. \\
\hline 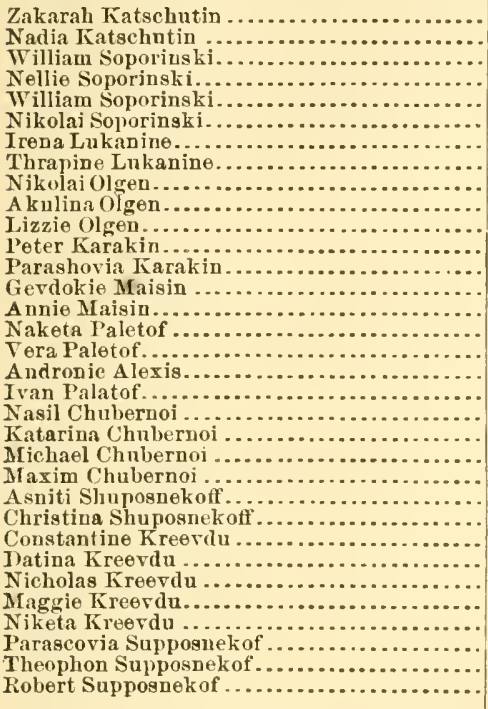 & $\begin{array}{r}45 \\
30 \\
25 \\
20 \\
13 \\
4 \\
60 \\
23 \\
50 \\
22 \\
5 \\
24 \\
19 \\
50 \\
40 \\
26 \\
25 \\
45 \\
16 \\
35 \\
25 \\
10 \\
6 \\
30 \\
22 \\
51 \\
32 \\
12 \\
10 \\
10 \\
40 \\
5 \\
1\end{array}$ & 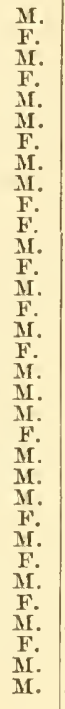 & 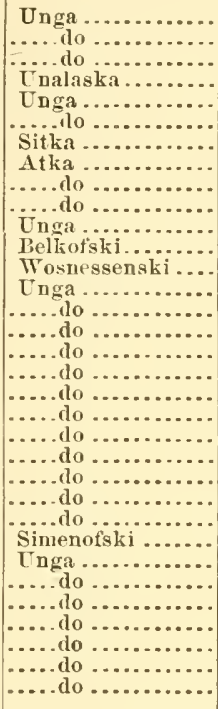 & $\begin{array}{l}\text { Irena's son. } \\
2 \text { children; hunter. } \\
\text { No clildren; hunter. } \\
\text { Do. } \\
\text { Do. } \\
\text { Single; hunter. } \\
\text { Do. } \\
2 \text { chiliren; hunter. } \\
\text { No children; hunter. } \\
\text { Chief; } 4 \text { children. }\end{array}$ \\
\hline
\end{tabular}

\section{RECAPITULATION.}

Males............................................................................. 20

Females .......................................................................... 13

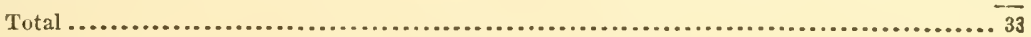

Census of Tosnessenski Island.

\begin{tabular}{|c|c|c|c|c|}
\hline Name. & Age. & Sex. & Where born. & Remarks. \\
\hline 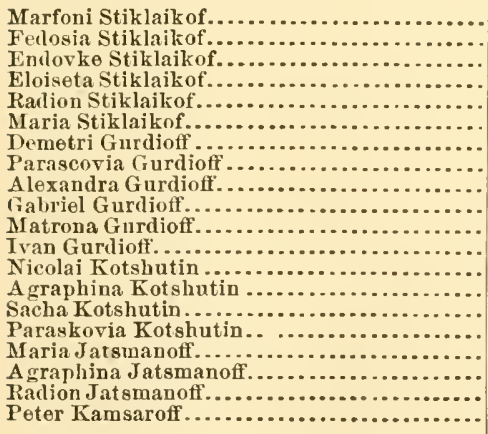 & $\begin{array}{r}30 \\
26 \\
6 \\
4 \\
1 \\
13 \\
\cdots \\
50 \\
18 \\
19 \\
12 \\
5 \\
23 \\
22 \\
5 \\
(a) \\
38 \\
6 \\
2 \\
24\end{array}$ & $\begin{array}{l}\text { M. } \\
\text { F. } \\
\text { F. } \\
\text { M. } \\
\text { F. } \\
\text { F. } \\
\text { F. } \\
\text { F. } \\
\text { M. } \\
\text { M. } \\
\text { F. } \\
\text { F. } \\
\text { F. } \\
\text { F. } \\
\text { M. }\end{array}$ & 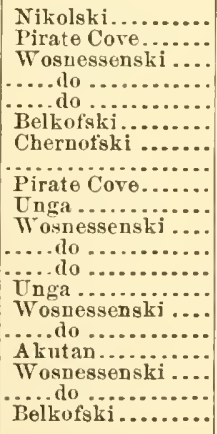 & $\begin{array}{l}3 \text { children; hunter. } \\
\text { Wife. } \\
\text { Orplaan. } \\
\text { 4 children; hunter. } \\
\text { Hunter. } \\
2 \text { children; hunter. } \\
\text { Wife. } \\
\text { Widow; } 2 \text { children. } \\
\text { No family; hunter. }\end{array}$ \\
\hline
\end{tabular}

a Eight months.

RECAPITULATION.

Mrales........................................................................... 9

Females ............................................................................. 11

Total ............................................................... 20 
Census of Belkofski.

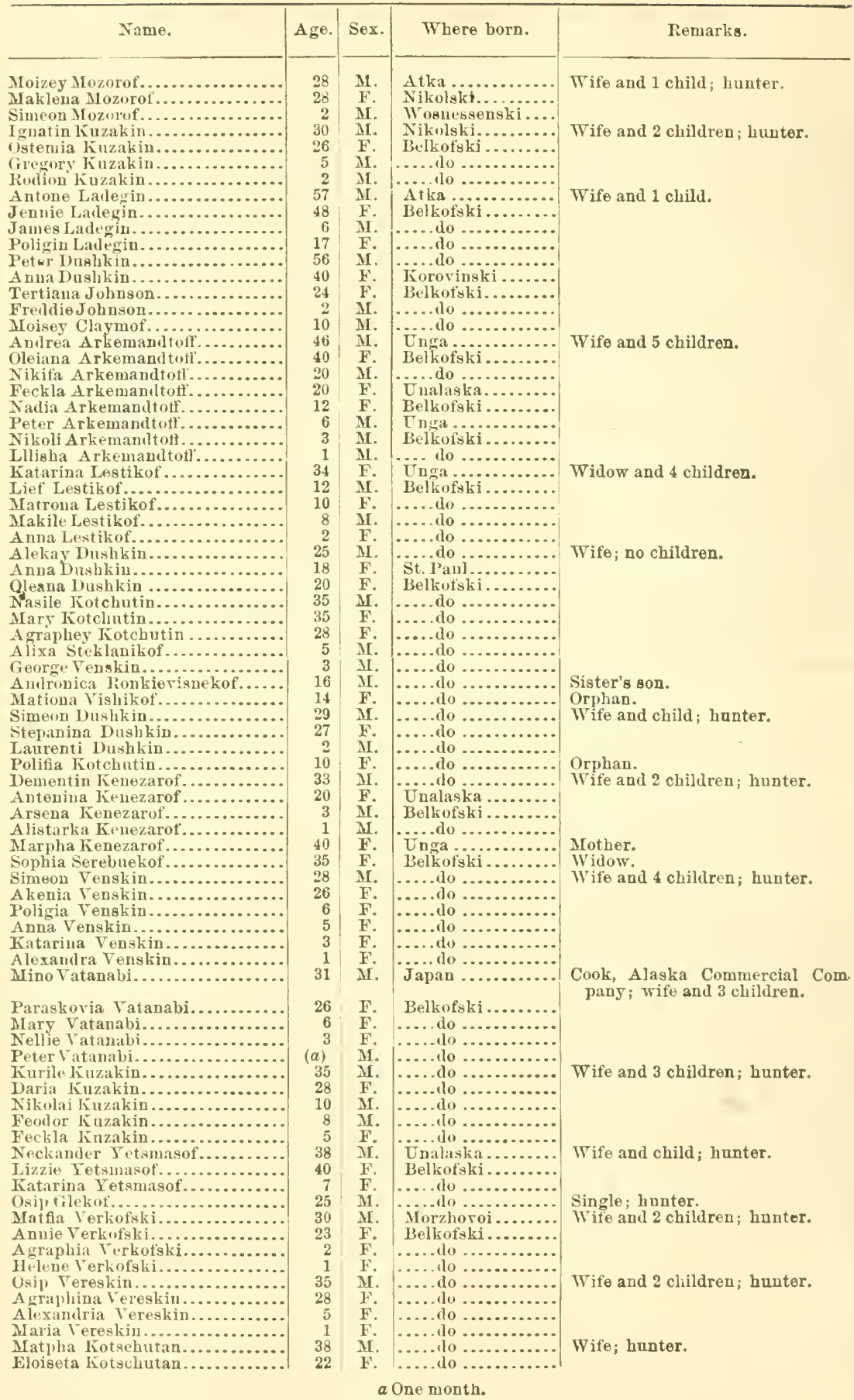


Census of Belkofski-Continued.

Name.

Ivan Ǩnzakin

Ivan Arkinand tot .

Katrin A

Peter Arkinandtof...

Gregory Golishof..

Alexandra Golishof.

Ivan Golishof.

Nikolai Kulzarof.

Lukela Kulzarof..

Marpha Kulzarof.

Yacor Vlashof...

Iokevti Vereskin.

Anatasia Vereskin

I van Vereskin.

Severe Vereskin.

Ivan Welgenenof.

Milania Welgenenof.

Katrina $W$ elgenenof.

Feckla Welgenenof

Neketa Grassinot

Italia Grassin of

Radion Grassinof.

Varvara Vereskin.

E. P. A lexine.

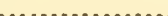

Olga A lexine.

Olga Alexine

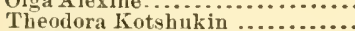

Constantine Panloft.

Alexandra Panloft:

Coustantine I'anloft

Laurent Kuzakin

Iolek Kuzakin .

I'oligea Kuzakin.

Vauvara Kinzakin

Feodote l'latnek of.

Gregory Grassin of

Fedore Platnek of

Poligea Venskin.

Fecla Venskin.

Irena Venskin..

Deunetri V'lask of

Miaria Vlaskof.

Ivan Vlaskof....

Rupk Karikin.

n.............

Eimelian Karakin .................

Sopdia Karakin .

Lujka Karakin...

Nikolai Kuzakin.

Anna Kuzakin....

Petna Veresk

Padion Dushkin.

Amnie Dushkin.

Mary Dushkin...

Peter Dnslikin...

Fedosia Dushkin.

Ivan Dush kin....

Matrona Dushkin
Mrs. Ainsworthy

Mrs. Ainsworthy.

Olga Ainsworthy

Wasila Galishof.

A gnes Galishof.

A rkup Masheenen

Evdokie Masheenen.

Fedoria Masheenen.

Maria Masheenen.

Marpha Masheenen.

Eopsik Kusakin .

(n............

Nikolai Knsakin.

Ivan Vereskin ...

Seneway Vereskin.

Garril Vereskin

Annie Ver skin

Ermoli Kotshutin................

\begin{tabular}{|c|c|c|c|}
\hline Age. & Sex. & Where born. & Romarks. \\
\hline 20 & MI. & Belkafski. & Single. \\
\hline 60 & M. & Unga... & Russian. \\
\hline 13 & F. & Belkofski... & Grandlchild. \\
\hline 15 & M. & ....do do............ & Do. \\
\hline 33 & M. & ...do ............. & Wife and 1 child; hnnter. \\
\hline $\begin{array}{l}30 \\
15\end{array}$ & Mi. & $\begin{array}{l}\text { Maknslin } \ldots . . . . \\
\text { Belkotski.......... }\end{array}$ & \\
\hline 55 & M. & .....do do........... & Do. \\
\hline $\begin{array}{r}32 \\
8\end{array}$ & F. & $\begin{array}{l}\text { Unalaska... } \\
\text {..... do ...... }\end{array}$ & \\
\hline 27 & if. & Belkofski... & Single. \\
\hline 55 & MI. & ...... do ....... & Wife and 2 children; huntez. \\
\hline 46 & F. & ..... do ....... & \\
\hline $\begin{array}{r}18 \\
5\end{array}$ & F. & iforzhovoi... & Single. \\
\hline 35 & M. & Belkot'ski... & Wife and 2 children; hunter. \\
\hline 30 & $\mathrm{~F}$. & ....do do....... & \\
\hline $\begin{array}{r}10 \\
4\end{array}$ & $\mathrm{~F}$. & 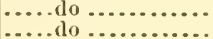 & \\
\hline 40 & Mi. & .... do do...... & Wife and I child; hunter. \\
\hline 30 & $\mathrm{~F}$. & .....do do...... & \\
\hline $\begin{array}{r}4 \\
45\end{array}$ & F. & .... do $\ldots$........ & \\
\hline 48 & II. & Russian ... & Russian priest, wife and child. \\
\hline 26 & F. & .....do ....... & \\
\hline 5 & F. & ¡...do ......... & \\
\hline $\begin{array}{l}14 \\
27\end{array}$ & M. & $\begin{array}{l}\text { Rosnessenski } \\
\text { Russia........ }\end{array}$ & Deacon, wife and child. \\
\hline 17 & F. & Belkufski... & 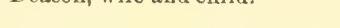 \\
\hline (a) & F. & .....do ...... & \\
\hline 50 & II. & ..... do ....... & Wife and 3 children; hunter. \\
\hline 40 & F. & Wosnessenski.... & \\
\hline $\begin{array}{r}12 \\
3\end{array}$ & $\mathrm{~F}$. & Belkofski........... & \\
\hline 1 & $\mathrm{~F}$. & ................... & \\
\hline 50 & M. & .....do do...... & Widower and 1 child; hunter. \\
\hline 18 & if. & ..... do ....... & Single. \\
\hline 8 & M. & ;i...do ............. & Widam and 5 bildmon \\
\hline 38 & F. & Wosnessenski .... & Widow and 5 children. \\
\hline $\begin{array}{r}11 \\
5\end{array}$ & F. & Belkofski.......... & \\
\hline 29 & M. & ....do do........... & Wife and 2 children; hunter. \\
\hline 25 & $\mathrm{~F}$. & ..... do ....... & \\
\hline 8 & M. & ......do ....... & \\
\hline 1 & MI. & .....do............ & \\
\hline $\begin{array}{l}55 \\
29\end{array}$ & M. & ..... do ............. & $\begin{array}{l}\text { Wife; hunter. } \\
\text { Widower. } 1 \text { child: hunter. }\end{array}$ \\
\hline 27 & F. & ....do do........... & Wife of Rupk. \\
\hline 2 & II. & .....do ........ & \\
\hline 50 & M. & ..... do ... & Wite and 2 chilüren; hunter. \\
\hline 60 & F. & & \\
\hline $\begin{array}{l}\mathbf{5} \\
\mathbf{2}\end{array}$ & $\mathrm{MI}$. & 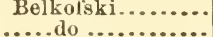 & \\
\hline 19 & M. & ..... do ........ & Single. \\
\hline 39 & M. & ..... do ..... & Chief; widower; 1 child. \\
\hline 12 & $\mathrm{~F}$. & ..... do .............. & Simolo \\
\hline $\begin{array}{l}25 \\
30\end{array}$ & Hi & ..... do no........... & Single. \\
\hline 20 & $\mathrm{~F}$. & jiorzhovoi........... & Wife. \\
\hline 17 & Mi. & ..... do .... & Single; hunter. \\
\hline 60 & $\mathbf{F}$. & Enalaska.......... & \\
\hline 30 & F. & Belkofski.......... & Widow and 2 children. \\
\hline $\begin{array}{l}15 \\
14\end{array}$ & F. & Ukatik........... & At school Unalaska \\
\hline $\begin{array}{l}1+1 \\
35\end{array}$ & Fi. & $\begin{array}{l}\text { Nikolfski........... } \\
\text { Belkofski........ }\end{array}$ & $\begin{array}{l}\text { At sehool, Unalaska, } \\
\text { Wife; bunter. }\end{array}$ \\
\hline 50 & $\mathrm{~F}$. & ... do do & \\
\hline 36 & MI. & .....do ............ & Wife, 3 children; hunter. \\
\hline 36 & F. & Paulof Bay ........ & \\
\hline 7 & F. & Belkofski.......... & \\
\hline$\frac{4}{1}$ & $\mathbf{F}$. & ..... do $\ldots . . . . . .$. & \\
\hline 35 & M. & {$[\ldots$ do $\ldots . . . . . . . .$.} & W ife, 1 child; hunter. \\
\hline 35 & F. & Panlof Bay....... & \\
\hline 7 & $\mathrm{MI}$. & Belkofski.......... & \\
\hline 50 & Mr. & Panlof Bay....... & Wife, 2 children; hunter. \\
\hline $\begin{array}{l}36 \\
13\end{array}$ & $\mathrm{~F}$. & Belkotski.......... & \\
\hline $\begin{array}{r}13 \\
6\end{array}$ & $\mathrm{H}$. & Wosmessenski.... & \\
\hline 55 & M. & Panlof Bay....... & Widower; hunter. \\
\hline
\end{tabular}


Census of Belkofski-Continued.

\begin{tabular}{|c|c|c|c|c|}
\hline Name. & Age. & Sex. & Where born. & Remarks. \\
\hline 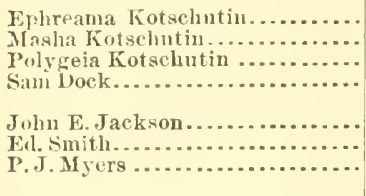 & $\begin{array}{l}50 \\
49 \\
11 \\
50 \\
\\
38 \\
35 \\
42\end{array}$ & $\begin{array}{l}\text { F. } \\
\text { F. } \\
\text { M. } \\
\text { M. } \\
\text { M. }\end{array}$ & 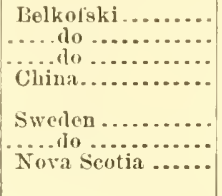 & $\begin{array}{l}\text { Widow. } \\
\text { Cook, Alaska Commercial Co.; } \\
\text { single. } \\
\text { Single, hunter. } \\
\text { Do. } \\
\text { Storelieeper, Alaska Commercial } \\
\text { Co. }\end{array}$ \\
\hline
\end{tabular}

RECA PITULA'TION.

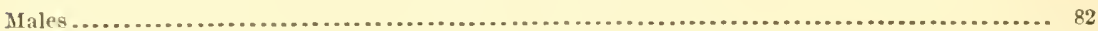

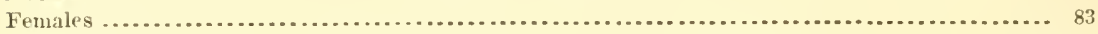

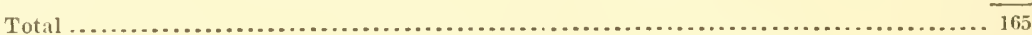

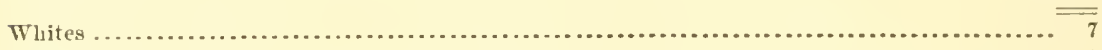

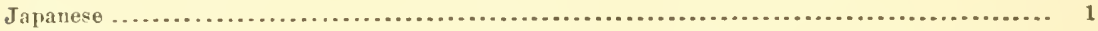

Chinese ...................................................................... 1

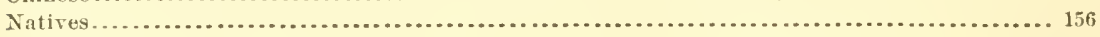

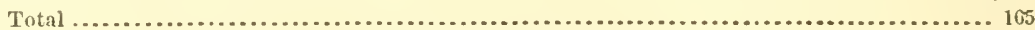

Census of Samnak Island.

\begin{tabular}{|c|c|c|c|c|}
\hline Name. & Age. & Sex. & Where born. & Remarks. \\
\hline 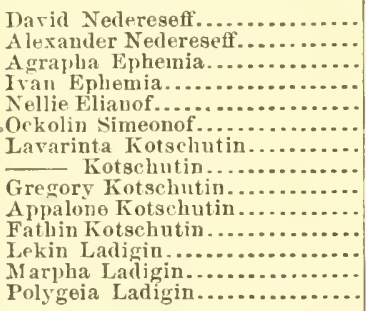 & $\begin{array}{r}50 \\
39 \\
50 \\
37 \\
9 \\
30 \\
30 \\
30 \\
2 \\
20 \\
20 \\
40 \\
30 \\
8\end{array}$ & $\begin{array}{l}\text { Mr. } \\
\text { F. } \\
\text { H. } \\
\text { F. } \\
\text { F. } \\
\text { H. } \\
\text { H. } \\
\text { M. } \\
\text { M. } \\
\text { M. } \\
\text { F. } \\
\text { F. }\end{array}$ & 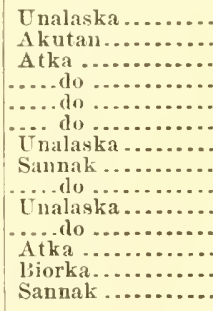 & $\begin{array}{l}\text { Hunter; no childen. } \\
\text { Widow; } 1 \text { child. } \\
1 \text { clild; hunter. } \\
\text { Wife. } \\
\text { Brother; single; hunter. } \\
\text { Cousin; single; hunter. } \\
1 \text { child; hunter. }\end{array}$ \\
\hline
\end{tabular}

\section{RECAPITULATION.}

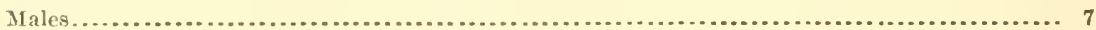

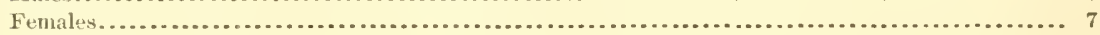

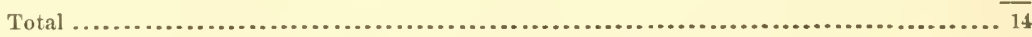

Census of Morzhovoi rillage, July $8,1897$.

\begin{tabular}{|c|c|c|c|c|}
\hline Name. & A ge. & Sex. & Th here born. & Remarks. \\
\hline Gregori I)ruskin. & 47 & M. & Old Morzhoroi.... & Husband. \\
\hline Mary Druskin.... & 38 & F. & Unimak ....... & Wife. \\
\hline Trophin Druskin... & 13 & M. & Morzhovoi........ & \\
\hline Anisia Druskin.... & 16 & F. & ..... do ........ & \\
\hline Gregori bruskin... & 10 & M. & ..... rlo ............. & Children. \\
\hline Ivan Druskin...... & 5 & M. & ..... do ....... & \\
\hline Comstantine Drusktn. & 2 & M. & ..... do ......... & \\
\hline Plillip Iruskin .... & 35 & Mi. & Oid Morz hovoi. & Husband. \\
\hline Tarvari Druskin................... & 23 & F. & Belkofski....... & Wife. \\
\hline Daria Druskin. & 3 & F. & Morzhoroi.... & Child. \\
\hline Kaprian Kuehitskin. & 63 & $M$. & Belkofaki..... & \\
\hline Ivan Jochlkotf I & 39 & $\mathbf{M}$. & Unimak... & Husband. \\
\hline Alexandra Mochikoft........... & 37 & $\mathrm{~F}$. & old Morzhovoi. & Wife. \\
\hline Ivan slochikoff II.. & 23 & i. & Tuimak & Husband. \\
\hline Alexandra Mochikotl .............. & 27 & $\mathbf{F}$. & Belkotski.. & Wife. \\
\hline Marie Mochikoff................ & 6 & F. & Morzhovoi...... & Child. \\
\hline
\end{tabular}


Census of Morzhovoi village, July 8, 1897-Continued.

\begin{tabular}{|c|c|c|c|c|}
\hline $\mathrm{Na}$ & Age. & Sex. & Where born. & Remarks. \\
\hline Tarsilio Mochikoft. & 38 & MI. & Atth ... & Husband. \\
\hline Stephanio Mochikot & 31 & $\mathrm{~F}$. & .....tlo .... & Wite. \\
\hline Jacob Garasimotf ... & 37 & MI. & Atka...... & Hnisband. \\
\hline Natalie Garasimoff & $\begin{array}{r}37 \\
7\end{array}$ & $\mathrm{~F}$. & -...do ...... & Wite. \\
\hline $\begin{array}{l}\text { Xinia Garasimoff ... } \\
\text { Cormel Garasimoff. }\end{array}$ & $\begin{array}{l}7 \\
3\end{array}$ & F. & Morzhovoi. & Children. \\
\hline $\begin{array}{l}\text { Cornel Garasimotf. - } \\
\text { Ostenia Garasimotif }\end{array}$ & $\begin{array}{l}3 \\
2\end{array}$ & M. & a...do & Children. \\
\hline Iran Druskin ....... & 17 & $\mathrm{MI}$. & .....do...... & \\
\hline Soplie Druskin.... & 13 & F. & ..... do. & Orphans. \\
\hline $\begin{array}{l}\text { Zachar Druskin ... } \\
\text { Hinia Brown }\end{array}$ & II & MI. & \#...do $\ldots .$. & \\
\hline $\begin{array}{l}\text { Hinia Brown ......... } \\
\text { Mary Brown....... }\end{array}$ & $\begin{array}{l}32 \\
13\end{array}$ & $\begin{array}{l}\mathrm{F} . \\
\mathrm{F}\end{array}$ & $\begin{array}{l}\text { Unimak .... } \\
\text { Morzhovoi. }\end{array}$ & $\begin{array}{l}\text { Widow. } \\
\text { At school, San Fran. }\end{array}$ \\
\hline Olga Brown... & & & 2010 & $\begin{array}{l}\text { At senool, san Fran- } \\
\text { siseo. }\end{array}$ \\
\hline William Brown... & $\begin{array}{l}9 \\
4\end{array}$ & Mi & .....do. & At sehool, Unalaska. \\
\hline Brown Benson..... & 39 & M. & Sweden & II usband. \\
\hline $\begin{array}{l}\text { Aeraphine Benson. } \\
\text { Iran Benson...... }\end{array}$ & 29 & F. & Atka.. & Wife. \\
\hline $\begin{array}{l}\text { Iran Benson ........ } \\
\text { Helene Benson..... }\end{array}$ & 11 & M. & Morzhovoi. & At sehool, Unalaska. \\
\hline $\begin{array}{l}\text { Helene Benson...... } \\
\text { Anne Benson ...... }\end{array}$ & 7 & F. & ...... do ..... & \\
\hline $\begin{array}{l}\text { Anne Benson ....... } \\
\text { Charles Peterson . }\end{array}$ & $\begin{array}{r}4 \\
30\end{array}$ & F. & ....do .... & \\
\hline $\begin{array}{l}\text { Charles Peterson ... } \\
\text { Martha Peterson .... }\end{array}$ & $\begin{array}{l}39 \\
23\end{array}$ & M. & Denmark :- & Husband. \\
\hline $\begin{array}{l}\text { Martha Peterson .... } \\
\text { Alexandra Peterson. }\end{array}$ & $\begin{array}{r}23 \\
6\end{array}$ & E. & Morzhoroi. & Wifo. \\
\hline $\begin{array}{l}\text { Alexandra Peterson } \\
\text { Nellie Peterson.... }\end{array}$ & $\begin{array}{l}6 \\
4\end{array}$ & $\mathrm{~F}$ & - . - edo ... & Children. \\
\hline Hanne Peterson... & 2 & $\mathbf{F}$ & .....do do & C Tindiren. \\
\hline Charles Rosenberg. & 39 & M. & Germany & Husband. \\
\hline Daria Rosenberg... & 30 & F. & Lnalaska. & Wite. \\
\hline Moses Lazarotf . .... & 13 & MI. & Morzhovoi.. & Child first husband. \\
\hline Geary ........ & 8 & F. & ..... do ... & Child second husband \\
\hline Varselie Rosenberg. & 5 & M. & $\ldots . . . d o . . .$. & Child third husband. \\
\hline Catharin Iiosenberg & 4 & F. & .....do ............. & Do. \\
\hline Ivan Rosenberg.... & $\begin{array}{r}1 \\
00\end{array}$ & M. & . & \\
\hline Charles Srensen.. - & 29 & M. & Sweden............ & \\
\hline Steplan Geriski... & 49 & $M$. & $\nabla$ asilisin & \\
\hline Terente Orcha & $\begin{array}{l}40 \\
38\end{array}$ & M. & Old Morzhovoi ... & Husband. \\
\hline Ileleno Orehardin... & 38 & $\mathrm{~F}$. & Unimak ........... & Wite. \\
\hline Nastasia Orchardin & $\begin{array}{l}10 \\
40\end{array}$ & Fi. & $\begin{array}{l}\text { Morzhoroi......... } \\
\text { Old Morzhoroi... }\end{array}$ & Husband. \\
\hline $\begin{array}{l}\text { Peter Zochoroff.... } \\
\text { Anna Zochorotf.... }\end{array}$ & $\begin{array}{l}40 \\
39\end{array}$ & F. & $\begin{array}{l}\text { Old Morzhoroi ... } \\
\text {....do .............. }\end{array}$ & $\begin{array}{l}\text { Husband. } \\
\text { Witte. }\end{array}$ \\
\hline $\begin{array}{l}\text { Anna Zochorotf..... } \\
\text { Kyprian Zochorott. }\end{array}$ & 2 & it. & jorzhoroi........... & \\
\hline $\begin{array}{l}\text { Ky prian Zochorott.. } \\
\text { Gregori Zoehorott... }\end{array}$ & (a) & II. & .....do . . & \\
\hline Ishmail Orchardin. & 36 & M. & Old Morzhovoi ... & Husband. \\
\hline Eresvet Orchardin.. & 40 & F. & Voga............. & Wite. \\
\hline Tatiana Orel & 6 & M. & MIorzhovoi........ & \\
\hline Orchardix & 3 & M. & $\ldots$...dn. & \\
\hline Arshen Rokavitshni & 18 & $M$. & Belkotski.......... & Child first hnsband. \\
\hline Koehmar Kuchitshin & 38 & M. & .....do . & Husband. \\
\hline Fecla Kuchitshin & 40 & F. & ... do ............. & Wife. \\
\hline Constantine Gar & 38 & M. & Old Morzhovoi ... & Husband. \\
\hline Maria Garasimotf. . & 24 & $F$. & Belkotski......... & Wite. \\
\hline $\begin{array}{l}\text { Ivan Garasimofi... } \\
\text { Soia Garasimoff.... }\end{array}$ & ${ }^{2}$ & $\frac{M 1}{\mathrm{~F}}$. & MIorzhovoi......... & \\
\hline $\begin{array}{l}\text { Soia Garasimoff...... } \\
\text { Iran Lazaroff...... }\end{array}$ & $\begin{array}{l}(b) \\
28\end{array}$ & II. & Unimak. & Hushand. \\
\hline $\begin{array}{l}\text { Iran Lazaroff.......... } \\
\text { Luekaria Lazaroff ... }\end{array}$ & $\begin{array}{l}20 \\
26\end{array}$ & $\mathrm{~F}$. & Unalaska........... & Wife. \\
\hline A kendin Lazaroti... & 3 & M. & Morzhovoi...... & \\
\hline Ale & (c) & MI. & & \\
\hline Constantin Veruskin & 39 & II. & Belkufski. & Father. \\
\hline Varsili Veruskin ........ & 8 & MI. & Morzhovoi........ & \\
\hline Karlam Veruskin..................... & $\begin{array}{l}5 \\
2\end{array}$ & Ml. & 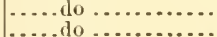 & \\
\hline $\begin{array}{l}\text { Sophif Veruskin .... } \\
\text { Demitr Lazaroff..... }\end{array}$ & $\begin{array}{r}2 \\
50\end{array}$ & ir. & Ünimak ... & \\
\hline 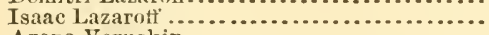 & 48 & M. & & Brothers. \\
\hline 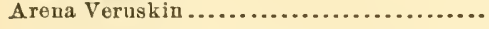 & 17 & $\mathbf{F}$. & Belkofski......... & Orphan. \\
\hline
\end{tabular}

\section{OLD MORZHOVOI FILLAGE.}

\begin{tabular}{|c|c|c|c|c|}
\hline 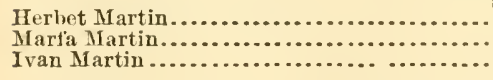 & $\begin{array}{r}38 \\
20 \\
(d)\end{array}$ & $\begin{array}{l}\text { MI. } \\
\text { Fi. }\end{array}$ & $\begin{array}{l}\text { United States..... } \\
\text { Makoshia........ } \\
\text { Old Mforzhoroi ... }\end{array}$ & $\begin{array}{l}\text { Husband. } \\
\text { Wife. }\end{array}$ \\
\hline
\end{tabular}


RECAPITULATION.

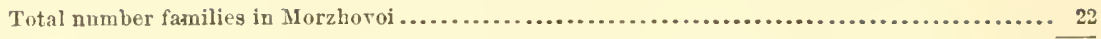

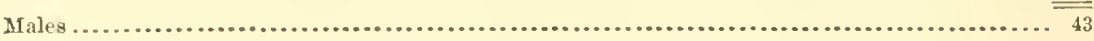

Females............................................................................... 35

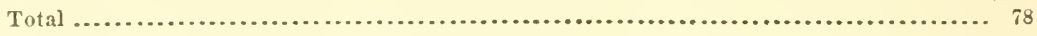

All the men were hunters and fishermen.

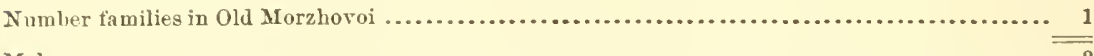

Males.......................................................................

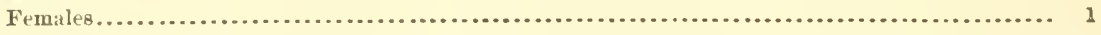

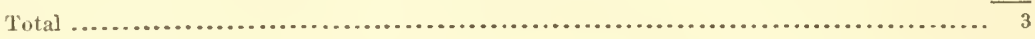

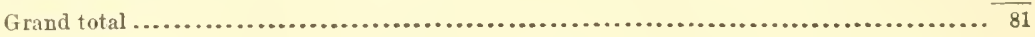

Census of Akutan village, Alaska, July $2,1897$.

\begin{tabular}{|c|c|c|c|}
\hline Name. & Age. & Sex. & Remarks. \\
\hline 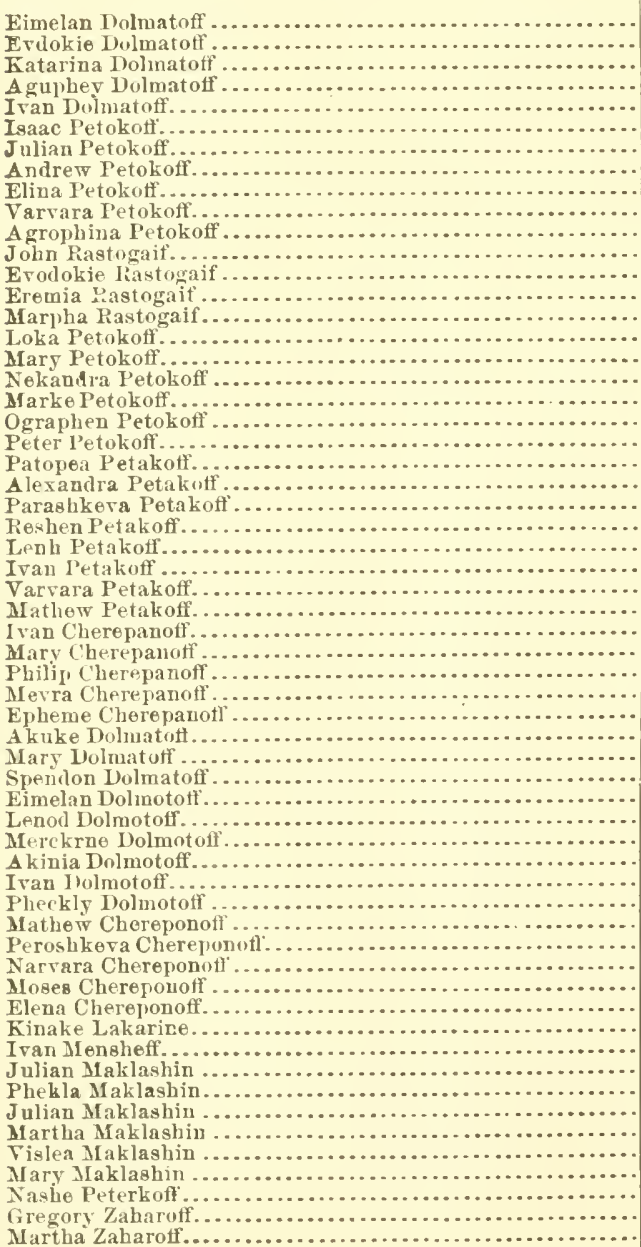 & $\begin{array}{r}32 \\
28 \\
6 \\
2 \\
(\alpha) \\
42 \\
41 \\
18 \\
13 \\
6 \\
3 \\
32 \\
21 \\
29 \\
51 \\
51 \\
40 \\
20 \\
7 \\
14 \\
7 \\
30 \\
28 \\
13 \\
10 \\
8 \\
6 \\
2 \\
18 \\
20 \\
19 \\
60 \\
60 \\
12 \\
37 \\
20 \\
3 \\
20 \\
63 \\
34 \\
30 \\
20 \\
17 \\
29 \\
27 \\
6 \\
3 \\
1 \\
20 \\
25 \\
40 \\
30 \\
13 \\
9 \\
5 \\
3 \\
50 \\
20 \\
17\end{array}$ & 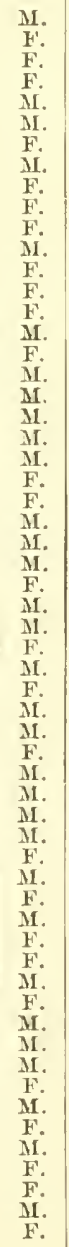 & $\begin{array}{l}\text { Wife and } 1 \text { child. } \\
\text { Wife and I child. } \\
\text { Unmarried. } \\
\text { Do. } \\
\text { Wife and no children. } \\
\text { Wife aud no children. } \\
\text { Wife and } 3 \text { children. } \\
\text { Unmarried. } \\
\text { Do. } \\
\text { Wife and } 4 \text { children. } \\
\text { Tnmarried. } \\
\text { Wife and no children. }\end{array}$ \\
\hline
\end{tabular}


Adnlt males.

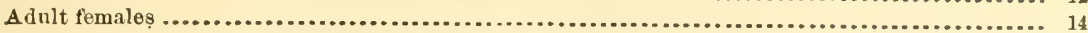

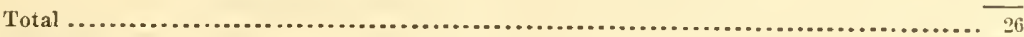

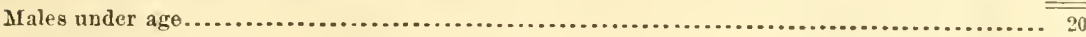

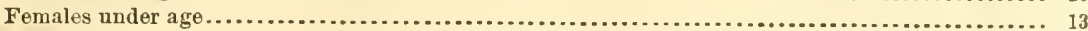

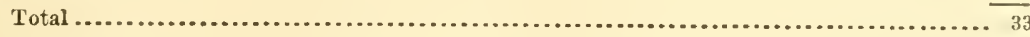

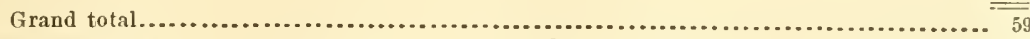

Number of families..............................................................

NoTE.-Those enumerated in the above were born on Akutan Island and all engaged in fishing for a living except Julian Macklashin, who keeps the Alaska Commercial Company store.

\section{Census of Unalaska Island.}

RUSSIAN MISSION SCHOOL.

\begin{tabular}{|c|c|c|c|c|}
\hline Name. & Age. & Sex. & Where born. & Remarks. \\
\hline 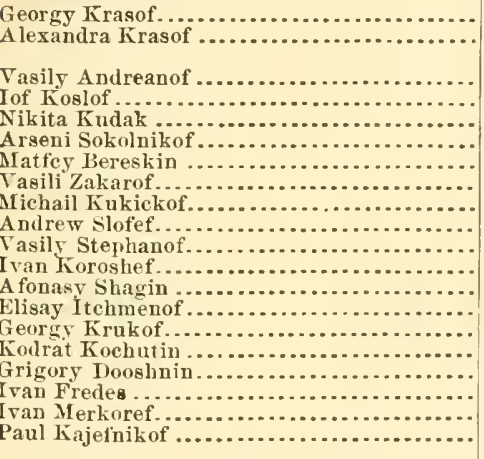 & $\begin{array}{l}29 \\
55 \\
14 \\
13 \\
16 \\
12 \\
11 \\
14 \\
11 \\
13 \\
12 \\
10 \\
15 \\
12 \\
13 \\
13 \\
13 \\
12 \\
13 \\
13\end{array}$ & $\begin{array}{l}\text { M. } \\
\text { F. } \\
\text { M. } \\
\text { MI. } \\
\text { MI. } \\
\text { MI. } \\
\text { Mi. } \\
\text { M. } \\
\text { MI. } \\
\text { MI. } \\
\text { Mi. } \\
\text { MI. } \\
\text { MI. } \\
\text { Mi. } \\
\text { MI. } \\
\text { MI. }\end{array}$ & 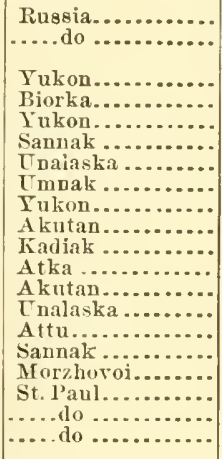 & $\begin{array}{l}\text { Wife; mo children. } \\
\text { Teacher, Russian } \\
\text { school. }\end{array}$ \\
\hline
\end{tabular}

VILLAGE OF ILIULIUK (UNALASKA).

\begin{tabular}{|c|c|c|c|c|}
\hline Simen Miloridof......................... & 58 & M. & Sitka & Wife; no children. \\
\hline Natali Mfilovidof........................... & 48 & $\mathrm{~F}$. & $\ldots$ do $\ldots . . . . . . .$. & \\
\hline 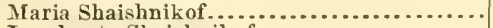 & 64 & F. & St. Panl............ & Widow; 3 children. \\
\hline 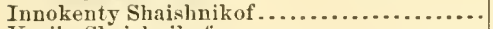 & 24 & $\mathbf{M}$. & Unalaska........ & \\
\hline 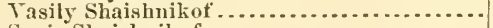 & 37 & M. & .... do .............. & Wife; 1 ehild. \\
\hline Sovia Shaishnik of . . . . . . . . . . . . . . . . . . & 23 & F. & Korovinski....... & Hunter; chief. \\
\hline 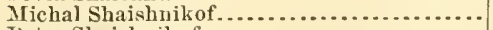 & 1 & MI. & Unalaska......... & \\
\hline n....................... & 29 & M. & ....do & Wife; no children. \\
\hline Anna Shaishnik of . . . . . . . . . . . . . . . . . . & 24 & F. & Chernotiski ........ & \\
\hline 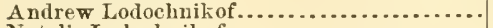 & 63 & M. & Atka $\ldots . . . . . . .$. & Widower; 1 child. \\
\hline 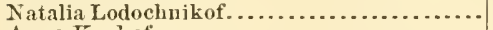 & 12 & F. & Tnalaska......... & \\
\hline 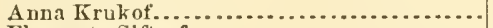 & 65 & F. & Atka $\ldots . . . . . .$. & Antrew's sister. \\
\hline Elesareta Siftsef. & 43 & F. & Unalaska......... & Widow; no children. \\
\hline Evdokia Golovin. & 47 & F. & Tnga $\ldots . . . . . .$. & 1)o. \\
\hline Andrian Golovin & 13 & M. & Korovingki... & Nejhew. \\
\hline Eran Olgin ...... & 43 & M. & Kadiak ............. & WVife; no children. \\
\hline$\ldots \ldots \ldots \ldots \ldots \ldots \ldots \ldots$ & 38 & $\mathbf{F}$. & $\ldots . . .10 \ldots . .$. & \\
\hline $\ldots \ldots \ldots \ldots \ldots \ldots \ldots \ldots \ldots$ & 21 & M. & ¿nalaska......... & \\
\hline 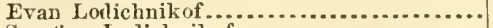 & 43 & MI. & $\ldots$ do ............. & Wife; 3 children. \\
\hline Seratina Lodichnikof ....................... & 40 & F. & Atka $\ldots . . . \ldots \ldots$ & \\
\hline 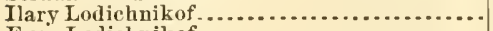 & 16 & MI. & Unalaska.... & \\
\hline 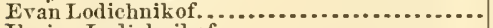 & 13 & M. & ..... do ... & \\
\hline 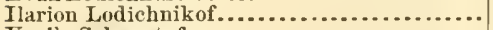 & 10 & $\mathbf{M}$. & ..... do .. & \\
\hline 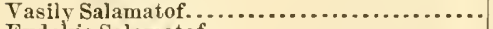 & 47 & MI. & Atka. & \\
\hline atof.................................... & 38 & F. & Unalaska.... & \\
\hline 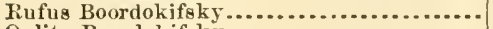 & 68 & M. & & \\
\hline Oulita Boordokifsky ............................ & 24 & F. & Dualaska .. & Wife. \\
\hline 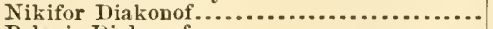 & 46 & M. & Unimak ........... & Four children. \\
\hline 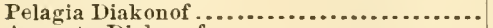 & 42 & $\mathbf{F}$. & Unalaska......... & Wife. \\
\hline 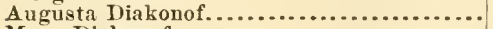 & 18 & F. & ..... do ............. & \\
\hline Muza Diakonof... & 22 & $\mathbf{F}$. & ..... do ............. & \\
\hline Anna Diak on of.. & 8 & $\mathbf{F}$. & ..... do. & \\
\hline $\bar{V}$ asily Diakonof & 6 & M. & & \\
\hline
\end{tabular}


Census of Tnalaska Island-Continued.

VILLAGE OF ILIULIUK (UNALASKA)-Centinued.

\begin{tabular}{|c|c|c|c|c|}
\hline Name. & Age. & Sex. & Where born. & Remarks. \\
\hline Evan Diakenof... & 38 & M. & Unimak & Wife; I child. \\
\hline A nastasia Diakont & 16 & $\mathrm{~F}$. & St. I'aul. & \\
\hline Ekaterina Diakenef. & 9 & $F^{2}$. & Unalaska & \\
\hline Peter Krukof ........ & 29 & M. & ......do .... & Wife; 2 children. \\
\hline A visia Tirukof... & 27 & $\mathrm{~F}$. & ...... llo.. & \\
\hline Efrosina Krukof.. & 7 & $\mathrm{~F}$. & .... 10. & \\
\hline Eftichey Kruk of. . & (a) & M. & - . . do . . & Tife. 1 child. \\
\hline $\begin{array}{l}\text { Hermai Krukef .. } \\
\text { Agripin Kirukof... }\end{array}$ & $\begin{array}{l}38 \\
24\end{array}$ & $\underset{\mathrm{F}}{\mathrm{M}}$ & -...todo.. & Wife; 1 child. \\
\hline $\begin{array}{l}\text { Agripin lirukof... } \\
\text { Elena Krukof .... }\end{array}$ & $\begin{array}{c}24 \\
1 \frac{1}{2}\end{array}$ & F. & & \\
\hline $\begin{array}{l}\text { Elena Krukof ...... } \\
\text { Pontan Krukof.... }\end{array}$ & 34 & ii. & .....tio. & \\
\hline Georgy Hansen..... & 24 & M. & .... de. & Do. \\
\hline $\begin{array}{l}\text { Maria Hansen........ } \\
\text { Seratina Hansen..... }\end{array}$ & 19 & F. & ......de. & \\
\hline $\begin{array}{l}\text { Seratina Hansen..... } \\
\text { Stephan Kruket..... }\end{array}$ & $\begin{array}{c}(b) \\
39\end{array}$ & & ßorlo. & \\
\hline Ekaterina Krukef.. & $\begin{array}{l}39 \\
38\end{array}$ & F. & ....de = & \\
\hline Kalista Repina.... & 61 & $\mathbf{F}$. & Unalaska & Widow. \\
\hline $\begin{array}{l}\text { Olga Repina....... } \\
\text { Ksenia TRepina... }\end{array}$ & 18 & F. & ....do... & \\
\hline $\begin{array}{l}\text { Ksenia Repina .... } \\
\text { Logiu Repin ..... }\end{array}$ & $\begin{array}{l}\text { (c) } \\
28\end{array}$ & Mr. & .... do & \\
\hline Ferdocia Repin... & 28 & F. & .....do . .. & Wife; no chilaren. \\
\hline Evan Repin ....... & 55 & MI. & Kalliak & Wife; 2 children. \\
\hline A polinaria Repin. & 43 & F. & Unaliska. & \\
\hline Kiptian Repin .... & 17 & M. & ..... do .. & \\
\hline $\begin{array}{l}\text { Stephan Repin..... } \\
\text { Boris Sorokiz..... }\end{array}$ & $\begin{array}{l}13 \\
40\end{array}$ & II. & .....de ... & \\
\hline $\begin{array}{l}\text { Boris Sorokin..... } \\
\text { Evdekia Sorokin . }\end{array}$ & $\begin{array}{l}40 \\
34\end{array}$ & $\mathrm{M}$. & ......do ........ & Wife; 2 children. \\
\hline $\begin{array}{l}\text { Evdekia Sorokin } \\
\text { Maria Sorokin... }\end{array}$ & $\begin{array}{r}34 \\
6\end{array}$ & F. & -....do do....... & \\
\hline $\begin{array}{l}\text { Maria Sorokin... } \\
\text { Glafira Sorokin ... }\end{array}$ & $\begin{array}{l}6 \\
3 \\
3\end{array}$ & F. & ....do .. & \\
\hline Peter Sorokin....... & 29 & M. & .....de... & Wife; no children. \\
\hline Tatiana Sorokin .... & 18 & F. & ..... do .. & - \\
\hline $\begin{array}{l}\text { Rafacil Sliabalin... } \\
\text { Evdokia Shabalin.. }\end{array}$ & 60 & M. & .....de. & Do. \\
\hline $\begin{array}{l}\text { Evdokia Shabalin } \\
\text { Neofit Slabalin... }\end{array}$ & 36 & F. & ...do.. & \\
\hline $\begin{array}{l}\text { Neofit Sluabalin..... } \\
\text { Simeon Been........ }\end{array}$ & $\begin{array}{l}13 \\
26\end{array}$ & M. & Yukon... & Wife; 2 children. \\
\hline Sotia lieen .......... & 33 & $\mathrm{~F}$. & Unalaska .......... & \\
\hline Maria Been...... & 3 & F. & ......do $0 . . . . . . . . . . .$. & \\
\hline $\begin{array}{l}\text { Peter Been ......... } \\
\text { Gregory Galaktionos }\end{array}$ & 1 & $M$. & ......do... & \\
\hline $\begin{array}{l}\text { Gregory Galaktiono } \\
\text { Eran Galaktionof... }\end{array}$ & $\begin{array}{r}11 \\
9\end{array}$ & $\begin{array}{l}\text { MI. } \\
\text { MI. }\end{array}$ & addo. & \\
\hline Sran Galaktionor... & 14 & $\mathrm{~F}$ & a.edo do & \\
\hline Nikolse Kichkef .. & 36 & MI. & .... do ... & \\
\hline Olga Kielikot ....... & 28 & F. & .....do. do & \\
\hline $\begin{array}{l}\text { Irima Kichkof....... } \\
\text { Evan Kichkof...... }\end{array}$ & $\begin{array}{l}4 \\
2\end{array}$ & $\mathrm{~F}$. & - n........ & \\
\hline $\begin{array}{l}\text { Evan Kichkof....... } \\
\text { Emelian Berekef ... }\end{array}$ & 32 & $\begin{array}{l}\text { M. } \\
\text { M. }\end{array}$ & Ünalaska.... & Wife; nochildren. \\
\hline Natalia Berekof... & 31 & F. & $\ldots$ do $\ldots . . . . . . .$. & \\
\hline Nicholye Artamonof... & 40 & MI. & Attin... & Do. \\
\hline Maria Artanonof. . & $\begin{array}{l}20 \\
30\end{array}$ & $\mathrm{~F}$. & Unalaska ........ & \\
\hline $\begin{array}{l}\text { Philip Tutak of.. } \\
\text { Martha Tutakef. }\end{array}$ & 30 & MI. & 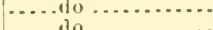 & Wife; 2 children. \\
\hline $\begin{array}{l}\text { Martha Tutakef. } \\
\text { Elena T'utakof... }\end{array}$ & 3.4 & F. & ....do ... & \\
\hline $\begin{array}{l}\text { Elena Tutakof..... } \\
\text { Miehail T'utakof ... }\end{array}$ & 4 & iI. & .... & \\
\hline Geergy Doroteof... & 30 & $\mathrm{M}$. & ..... do .. & Tifo; no children. \\
\hline Pelagia Dorofeof... & 23 & $\mathrm{~F}$. & ..... do ............. & \\
\hline Elena Newman .... & 47 & F. & ...... do .. & \\
\hline $\begin{array}{l}\text { Artemy Newman.. } \\
\text { Saral Newnan... }\end{array}$ & $\begin{array}{l}11 \\
21\end{array}$ & II. & .... do ... & \\
\hline $\begin{array}{l}\text { Sarali Newnan ... } \\
\text { Nadia Nowman... }\end{array}$ & 12 & $\mathrm{~F}$. & -...do do $\ldots$...... & \\
\hline Martha Sovorof.... & 44 & F. & Atka...... & Widow; 2 children. \\
\hline Lulka Soveref...... & 12 & MI. & Unalaska..... & \\
\hline Gabriel Sovorof... & 5 & M. & ......ile .......... & 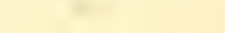 \\
\hline $\begin{array}{l}\text { Matrona Audersou...... } \\
\text { Inuokenty Anderson... }\end{array}$ & 6 & F. & ....de & \\
\hline $\begin{array}{l}\text { Inuokent } \\
\text { Stephan Reesef.............. }\end{array}$ & 36 & ir. & Kadiak. & Wife; no children. \\
\hline Julia Reesef ........ & 23 & F. & St. 1'aul... & \\
\hline Antrew Swanson...... & 24 & $\frac{M I}{x}$ & Unalaska.... & \\
\hline $\begin{array}{l}\text { Sopia Swanson..... } \\
\text { Fodora Clinker... }\end{array}$ & (b) & ir. & .....de do ........... & \\
\hline Fedora Clinker.... & 40 & M. & Kadiak........... & Wife; 1 child. \\
\hline Julia P'etelin...... & 30 & F. & Unalaska .......... & \\
\hline . & L2 & M. & iz...do ............. & \\
\hline Alexander Lee.... & 5 & M. & Morzhovoi ....... & \\
\hline $\begin{array}{l}\text { Evan Lee. } \\
\text { Alexander Nikiten }\end{array}$ & L & $\mathrm{M}$. & 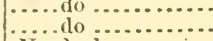 & \\
\hline Maria Wagner.... & 19 & F. & Unalaska..... & \\
\hline 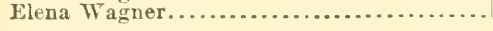 & 13 & F. & 1.....do ............. & \\
\hline
\end{tabular}


Census of Unalaska Island-Continued.

VILLAGE OF ILIULIUK (UNALASKA)-continued.

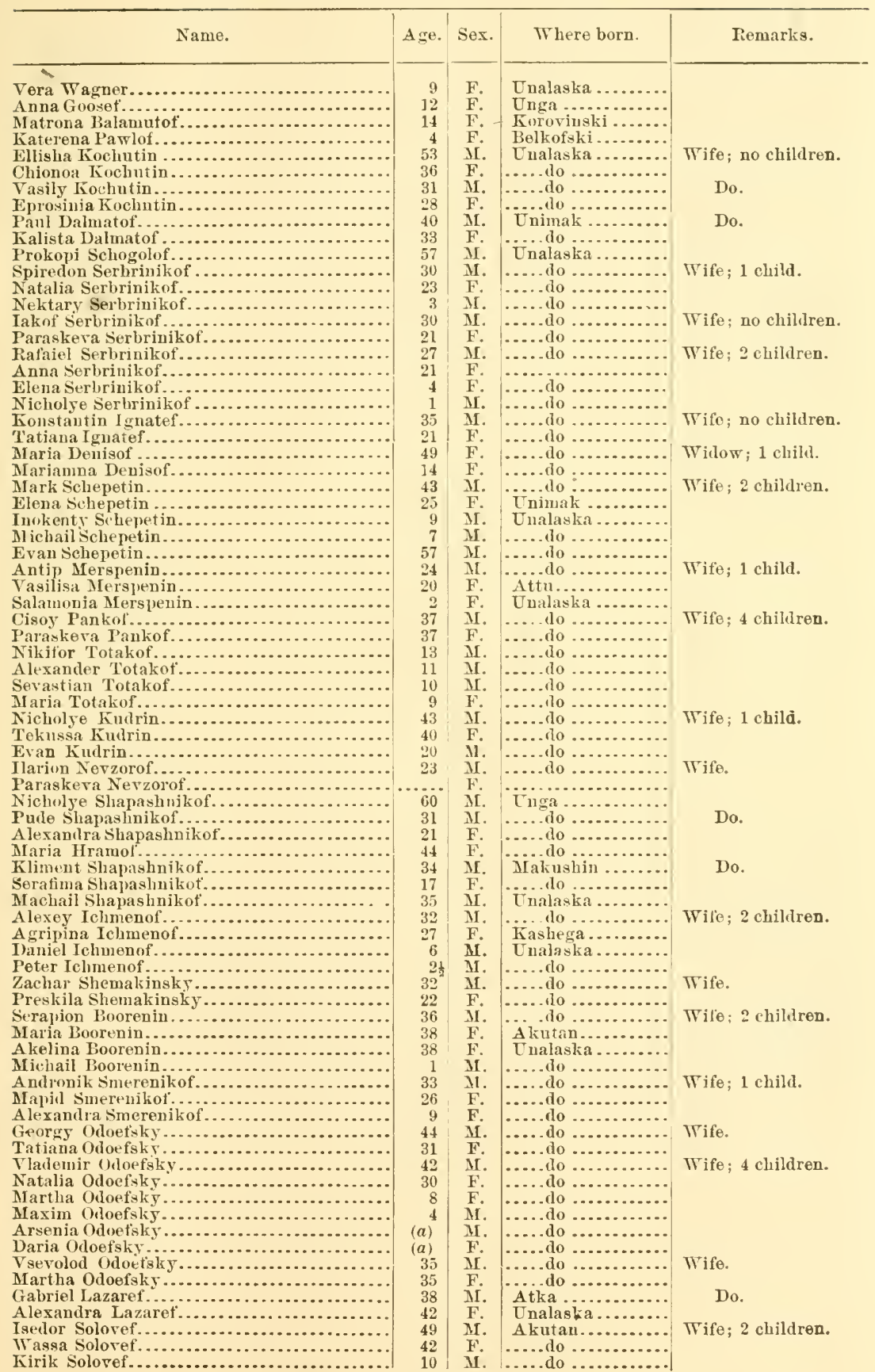


Census of Cnalaska Island-Continued.

VILLAGE OF ILIULIUK (UNALASKA)-continued.

\begin{tabular}{|c|c|c|c|c|}
\hline $\mathrm{Na}$ & Age. & Sex. & Where born. & Remarks. \\
\hline 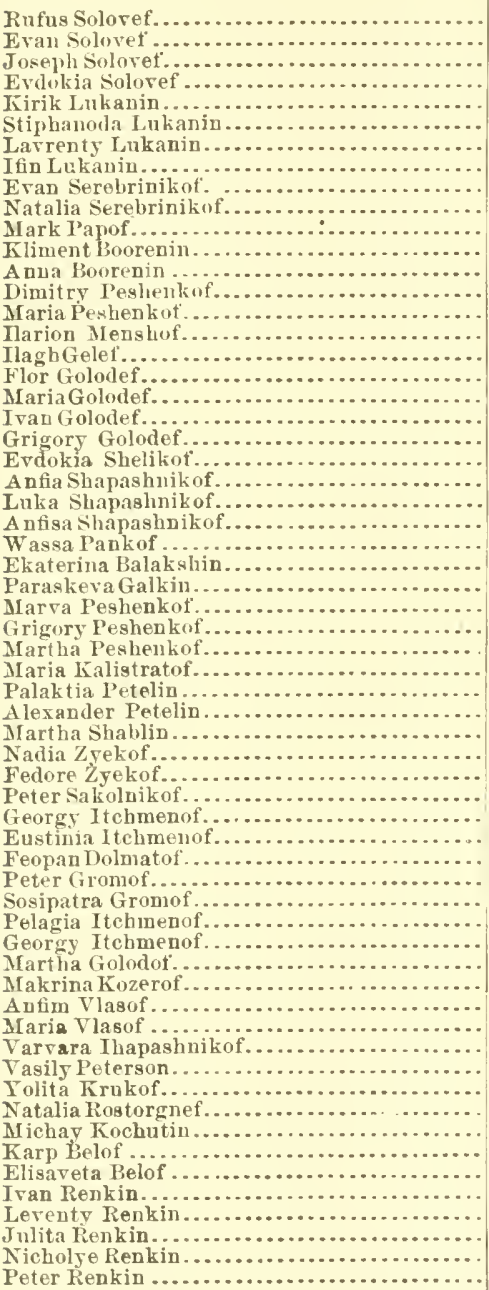 & $\begin{array}{c}7 \\
34 \\
38 \\
22 \\
28 \\
29 \\
21 \\
30 \\
35 \\
22 \\
38 \\
54 \\
20 \\
27 \\
26 \\
46 \\
24 \\
49 \\
35 \\
7 \\
5 \\
59 \\
32 \\
10 \\
(a) \\
57 \\
65 \\
75 \\
32 \\
11 \\
6 \\
49 \\
42 \\
5 \\
44 \\
41 \\
21 \\
20 \\
42 \\
42 \\
18 \\
26 \\
22 \\
58 \\
35 \\
43 \\
66 \\
22 \\
26 \\
15 \\
14 \\
12 \\
13 \\
9 \\
30 \\
24 \\
5 \\
5\end{array}$ & 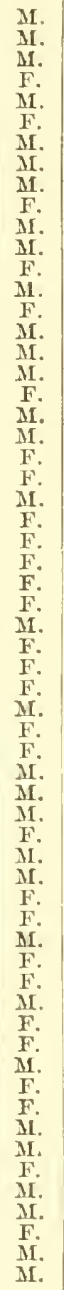 & 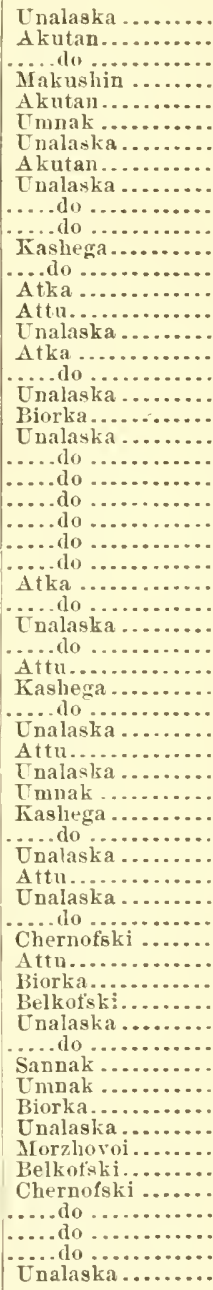 & $\begin{array}{l}\text { Wife. } \\
\text { Wife; } 1 \text { child. } \\
\text { Wife. } \\
\text { Do. } \\
\text { Do. } \\
\text { Wife; } 2 \text { children. } \\
\text { Widow. } \\
\text { Widlow; } 2 \text { children. } \\
\text { Widow. } \\
\text { Do. } \\
\text { Do. } \\
\text { Do. } \\
\text { Do. } \\
\text { Do. }\end{array}$ \\
\hline
\end{tabular}


Census of Biorka Island.

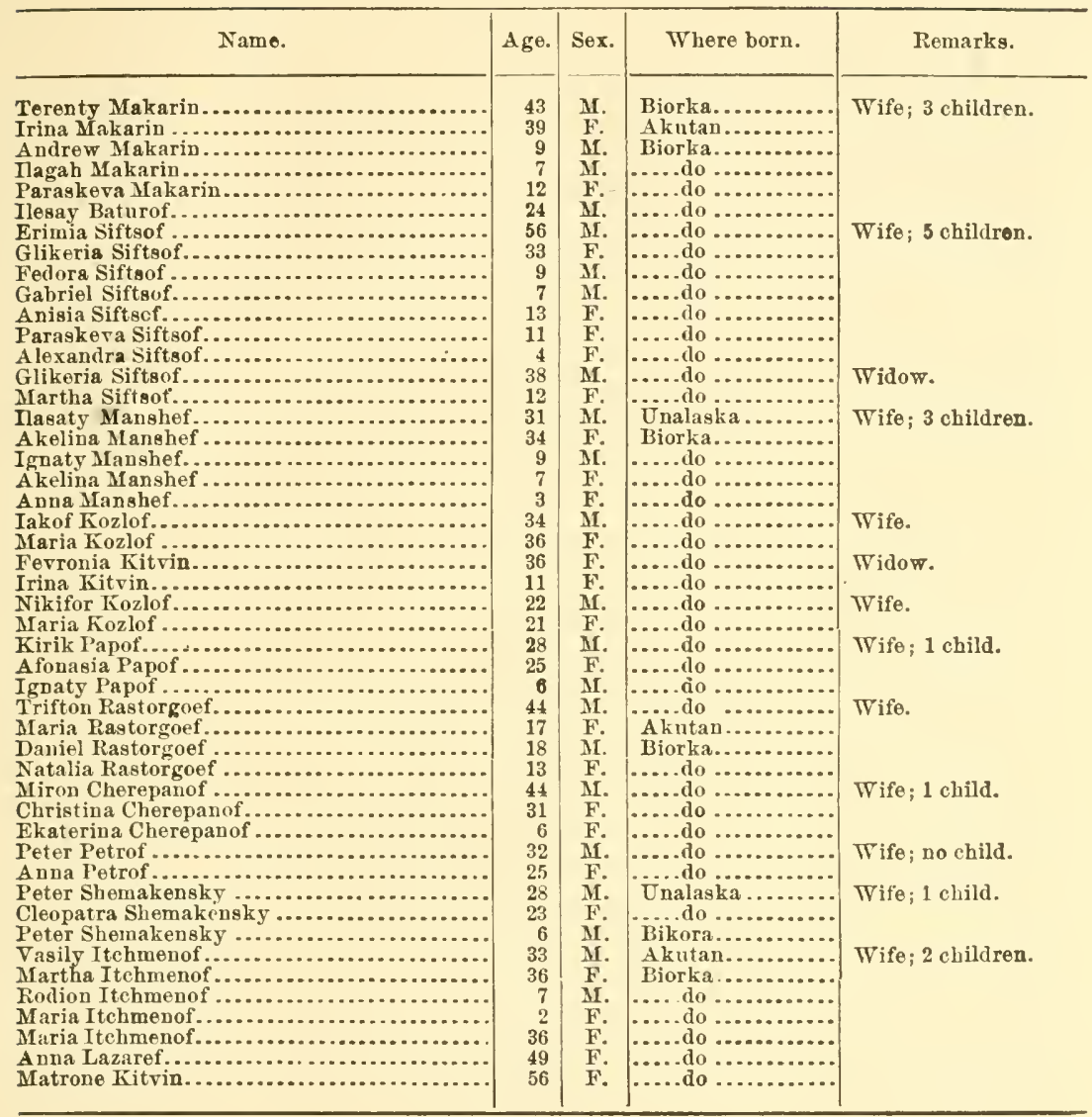


Census of Makushin.

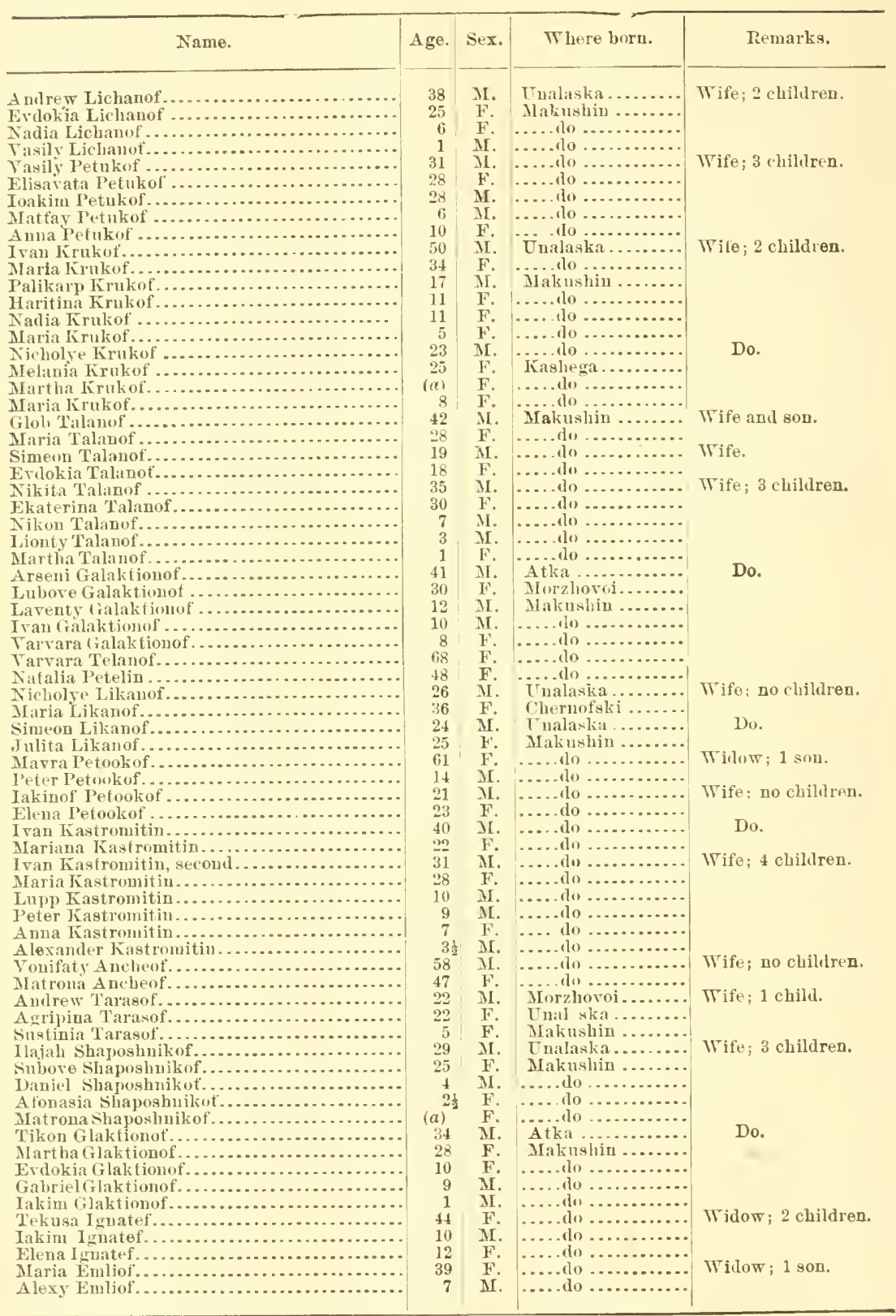

a Six months. 
Census of Tashega.

\begin{tabular}{|c|c|c|c|c|}
\hline $\mathrm{Na}$ & Age. & Sex. & Where born. & Remarks. \\
\hline 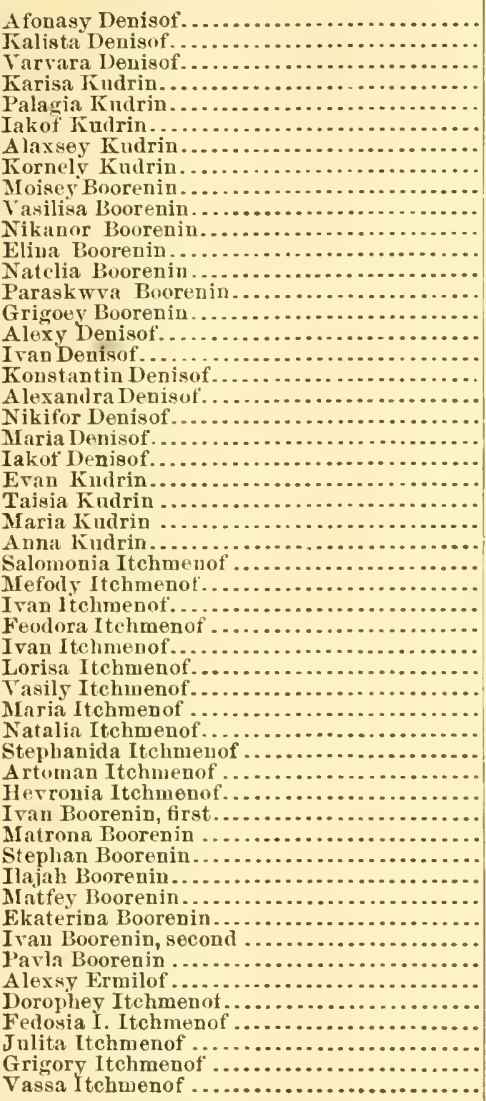 & 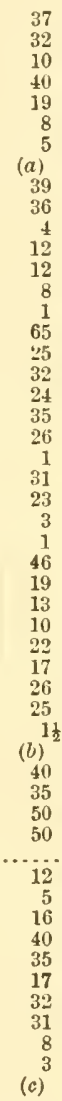 & 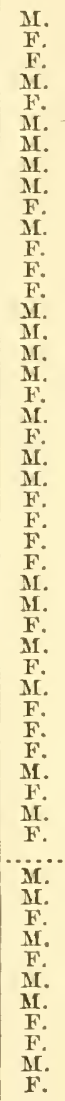 & 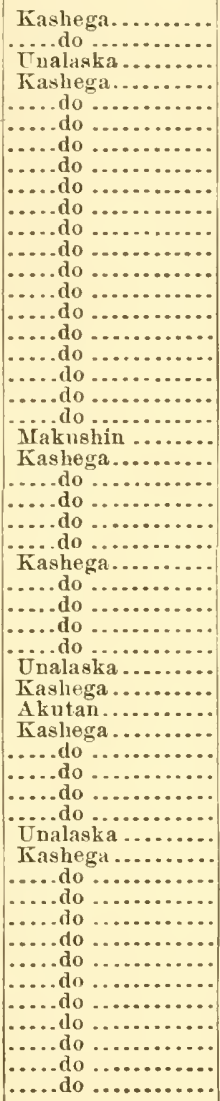 & $\begin{array}{l}\text { Wife; } 2 \text { children. } \\
\text { Widow ; } 3 \text { children. } \\
\text { Wife; no children. } \\
\text { Wife; } 2 \text { children. } \\
\text { Wife; no children. } \\
\text { Wife; } 4 \text { children. }\end{array}$ \\
\hline
\end{tabular}


Census of Chernofsti.

\begin{tabular}{|c|c|c|c|c|}
\hline Name. & Age. & Sex. & Where born. & Remarks. \\
\hline
\end{tabular}


Census of Umnak.

\begin{tabular}{|c|c|c|c|c|}
\hline Name. & Age. & Sex. & Where born. & Remarks. \\
\hline Nikifor Krukof . . . . . . . . . . . . . . . . . & 48 & M. & Unalaska........ & Wife; 8 children. \\
\hline 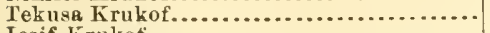 & 43 & F. & it.tlo ............. & \\
\hline 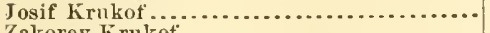 & 21 & M. & Umnak ............ & \\
\hline 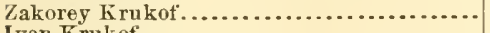 & 18 & M. & .... do do........... & \\
\hline 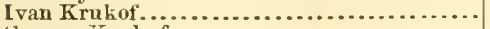 & 12 & M. & .... do ............ & \\
\hline 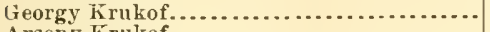 & 3 & MI. & ....do do............ & \\
\hline 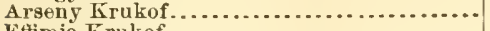 & 14 & Mi. & ..... do ............ & \\
\hline 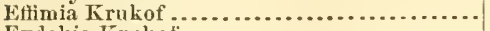 & 11 & F. & ..... do ............. & \\
\hline Evdokia Krukot $\ldots \ldots \ldots \ldots \ldots \ldots \ldots \ldots \ldots \ldots$ & 7 & F. & ..... do $\ldots . . . . . . .$. & \\
\hline & 4 & F. & ....do do .............. & \\
\hline 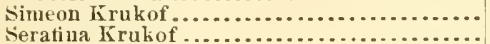 & 46 & M. & Enalaska......... & Wife; 6 children. \\
\hline & 38 & $\mathrm{~F}$ & Usunak ............ & \\
\hline 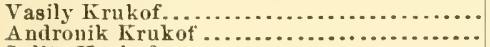 & 17 & M. & ..... do ............... & \\
\hline & 8 & $M$. & ......do & \\
\hline 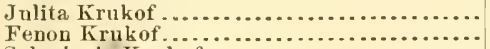 & 13 & F. & .....do ............. & \\
\hline 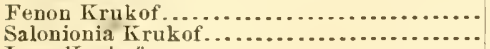 & 10 & F. & .....dlo .............. & \\
\hline & 6 & F. & . . . do ............ & \\
\hline $\begin{array}{l}\text { Ivan Krukof } \ldots \ldots \ldots \ldots \ldots \ldots \ldots \ldots \\
\text { Boris Besizikof } \ldots \ldots \ldots \ldots \ldots \ldots \ldots \ldots \ldots\end{array}$ & 7 & MI. & .... do ............. & \\
\hline & $\begin{array}{l}46 \\
41\end{array}$ & 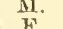 & 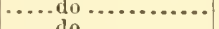 & Wife; 2 children. \\
\hline & $\begin{array}{l}41 \\
22\end{array}$ & Fi. & & \\
\hline $\begin{array}{l}\text { Peter Besizikof } \ldots \ldots \ldots \ldots \ldots \ldots \ldots \ldots \\
\text { Kiril Besizikof } \ldots \ldots \ldots \ldots \ldots \ldots \ldots \ldots \ldots \ldots\end{array}$ & 18 & M. & 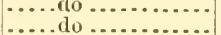 & \\
\hline 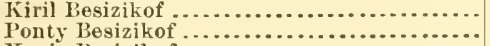 & 42 & M. & 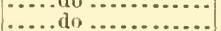 & Wife. \\
\hline (n) & 33 & $\mathrm{~F}$ & ...... do & Wife. \\
\hline Julia Shaposnikof. & 22 & $\mathrm{~F}$. & ..... do . & \\
\hline & 34 & M. & ..... do .. & Do. \\
\hline ..................... & 24 & $\mathbf{F}$ & .... do do............ & Do. \\
\hline . & 66 & M. & .... do do......... & Wife; 4 children. \\
\hline 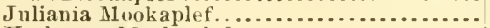 & 46 & F. & .... do ................... & \\
\hline Karlampy Mookaplef ...................... & 18 & M. & . . . 110 & \\
\hline Maria Mlookaplet ....... & 15 & $\mathrm{~F}$ & .... do ............ & \\
\hline 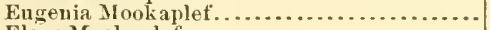 & 13 & F. & ....to. & \\
\hline 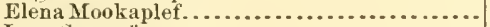 & 30 & F. & .....do.. & \\
\hline ...................... & 33 & M. & .....do. & Wife; 2 children. \\
\hline .................... & 28 & $\mathbf{F}$. & .....do.. & \\
\hline$\ldots \ldots \ldots \ldots \ldots \ldots \ldots \ldots$ & 6 & M. & 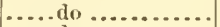 & \\
\hline $\ldots \ldots \ldots \ldots \ldots \ldots \ldots \ldots$ & 2 & MI. & .....do ............. & \\
\hline$\ldots \ldots \ldots \ldots \ldots \ldots \ldots \ldots$ & 20 & M. & ..... do ............ & \\
\hline 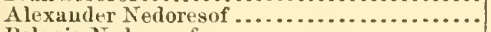 & 41 & MI. & .....do do............ & Wife; 5 children. \\
\hline Pelagia Nedoresof .......................... & 44 & $\mathbf{F}$. & ..... do ....... & \\
\hline Grigory Nedoresot . . . . . . . . . . . . . . . . . . . & 10 & M. & ..... do .... & \\
\hline 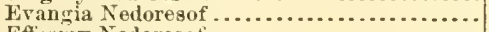 & 17 & $\mathrm{~F}$. & ..... do ... & \\
\hline 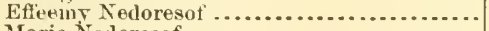 & 7 & II. & ...... llo .... & \\
\hline 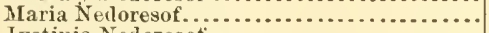 & 4 & F. & ......to ... & \\
\hline Jystinia Nedoresot $\ldots . . . . . . . . . . . . . .$. & 2 & F. & - . . . 10. & \\
\hline 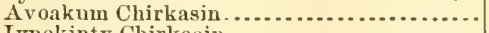 & 26 & MI. & ..... do .... & \\
\hline 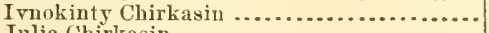 & 23 & F. & .... do .. & \\
\hline 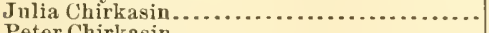 & 71 & $\mathbf{F}$. & .... do .. & \\
\hline 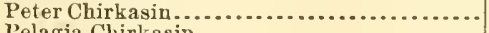 & 28 & M. & ....do... & Wife; 2 children. \\
\hline 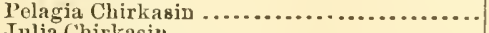 & 41 & F. & ..... do .... & \\
\hline 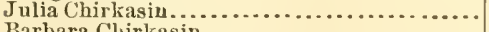 & 8 & F. & ..... do ... & \\
\hline 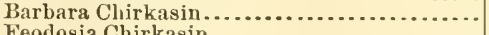 & 17 & F. & ..... do .. & \\
\hline . & 28 & $\mathrm{~F}$. & ..... do.. & \\
\hline 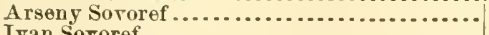 & 32 & MI. & .....do.. & \\
\hline 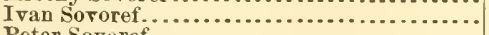 & 30 & ML. & .....do... & \\
\hline 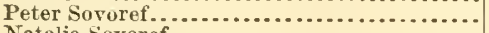 & 34 & $M$. & ..... do ... & Wife; no children. \\
\hline . . . . . & 25 & $\mathrm{~F}$. & ....do... & \\
\hline ................... & 35 & M. & ..... do .. & Do. \\
\hline . & 24 & F. & ..... do .. & \\
\hline Grigory Cherkasin. & 23 & MI. & ...... do.. & \\
\hline Konstantin Cherkas & 32 & M. & $\ldots$ do .. & \\
\hline 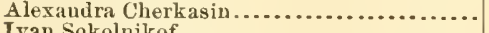 & 32 & $\mathrm{~F}$. & Chernotis & \\
\hline 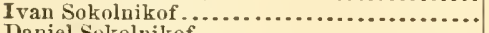 & 51 & $\mathrm{~F}$. & Umnak ............ & \\
\hline$\ldots \ldots \ldots \ldots \ldots \ldots$ & 29 & M. & ..... do . & \\
\hline Elena Sokolnikof $\ldots . \ldots \ldots \ldots \ldots \ldots$ & 25 & F. & .....do. & \\
\hline 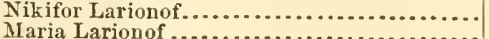 & 35 & $\mathrm{Mr}$. & ..... do. & \\
\hline 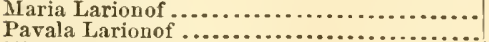 & 34 & F. & .....do. do . & \\
\hline $\begin{array}{l}\text { Pavala Larionof ..... } \\
\text { Timofey Dorofeof... }\end{array}$ & $\begin{array}{r}2 \\
39\end{array}$ & F. & .....do do & Do. \\
\hline $\begin{array}{l}\text { Timofey Dorofeof.. } \\
\text { Melania Dorofeof... }\end{array}$ & $\begin{array}{l}39 \\
37\end{array}$ & $\mathbf{F}$. & ..... do ... & Do. \\
\hline $\begin{array}{l}\text { Melania Dorofeof... } \\
\text { Ilarion Dorofeof..... }\end{array}$ & 17 & M. & ..... do do & \\
\hline $\begin{array}{l}\text { Ilarion Dorofeof..... } \\
\text { Irina Dorofeof....... }\end{array}$ & 39 & F. & $\ldots$ do $\ldots$ & \\
\hline $\begin{array}{l}\text { Irina Dorofeof ...... } \\
\text { Euginia Dorofeof.... }\end{array}$ & 4 & $\mathbf{F}$. & $\ldots$ do $\ldots$ & \\
\hline 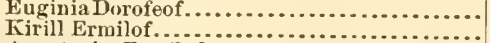 & $44^{2}$ & M. & .....do... & TVife; 1 child. \\
\hline 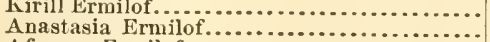 & 37 & F. & ......do. do. & Wite; 1 child. \\
\hline Anastasia Ermilot. & 8 & II. & ....... do do & \\
\hline Peter Pletnikof... & 35 & MI. & ......do. & \\
\hline Kevronia Pletnikof. & 29 & $\mathrm{~F}$. & .....do. & Wife; 2 children. \\
\hline Davil Pletnikof.... & 7 & M. & ..... rlo & \\
\hline 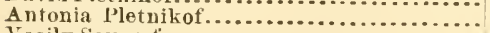 & 2 & F. & .... do & \\
\hline$\ldots \ldots \ldots \ldots \ldots \ldots \ldots$ & 35 & $M$. & ..... do & \\
\hline 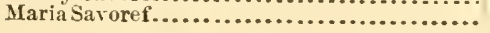 & 44 & F. & $\ldots \ldots$ do ............. & \\
\hline
\end{tabular}


Census of Cmnak-Continued.

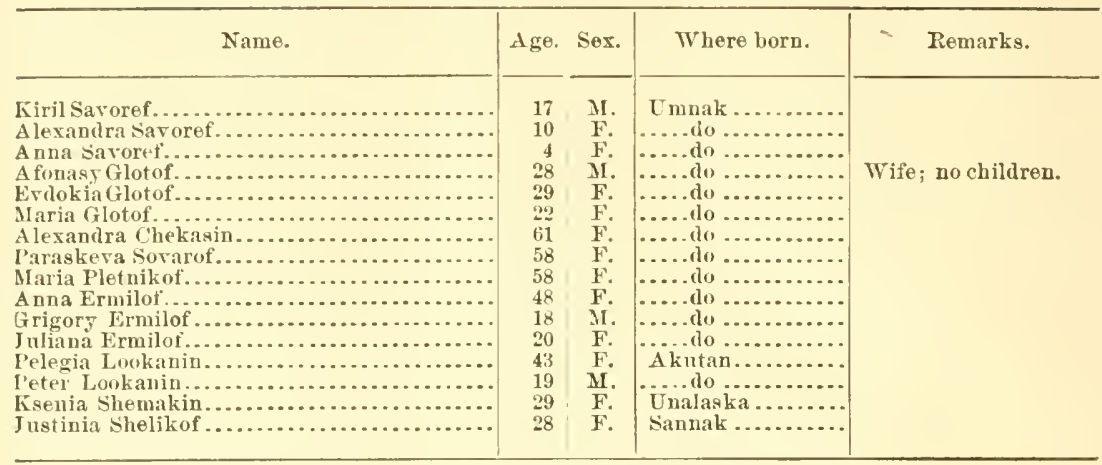

Census of Atka Island.

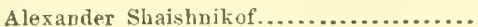

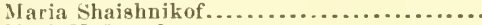

Maria Nefzorof....

Anna Svining.

Feodor Golay.

Kassian Golay.

Pelagia Golay.

A ppolon Golay.

Fkaterina Golay.

Matrona Golay.

Stephan Golay.

kintus Golay

Paraskeva Golay.

Konstantin Golay.

Anna Golay.

Sergy Golay.

Dionisy Peshenkof

Grigory Peshenk of

Georgy Mershenin.

Natalia Mershenin

Adrian Mershenin.

Michail Mershewin.

llarion Nlershenin.

Ivan Mershenin...

Akilina Mershenin.

Nicholay Nefzorof.

Agaplia Nefzorof.

Feodor Florushin.

Meropia Florushin

Michael Florushin

Natalia Florushin.

Anisia Floruslin.

Anna Florushin.

Wukol Nefzorof.

Afonasy Nefzorof.

Maria Nefzorof

Elima Nefzorot'.

Konstantin Nefzorof

Matrona Nefzorof.

Aroakm Tazaref.

Martha Lazaref..

Adrian Lazaref.

Iran Lazaref.

II ichael sinigerof

Zinovia Snigerof.

Isedor Snigerof.

A gappia Suigerof.

Anna Snigerof.

Fvtike snigerof

Andrew Snigerot

Evdokia Śnigerof.

Akilina Snigerof

Josef Snigerof .

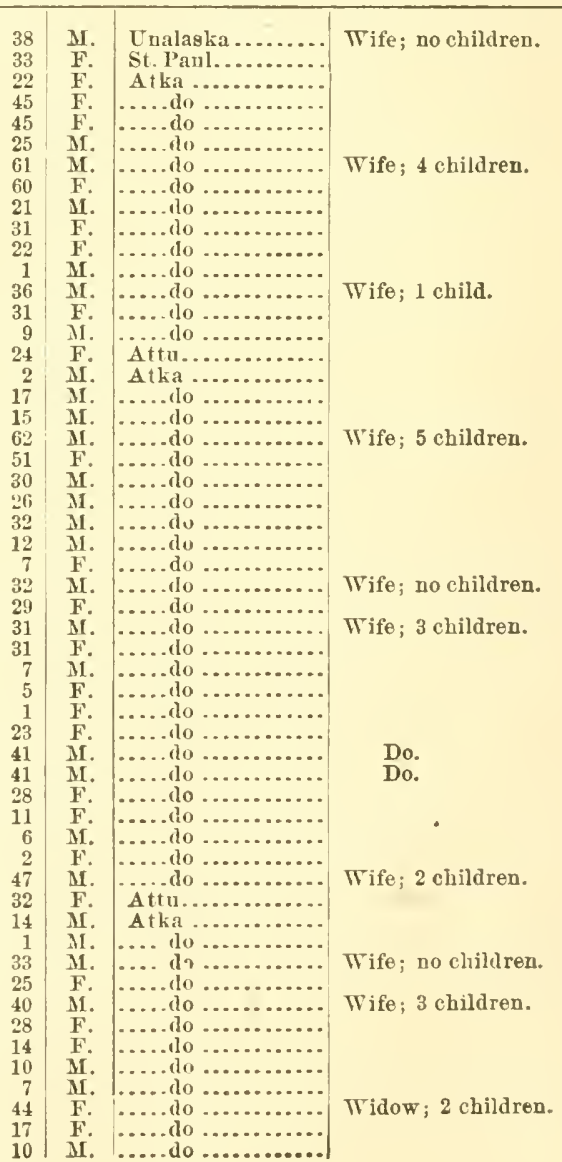


Census of Atka Island-Continued.

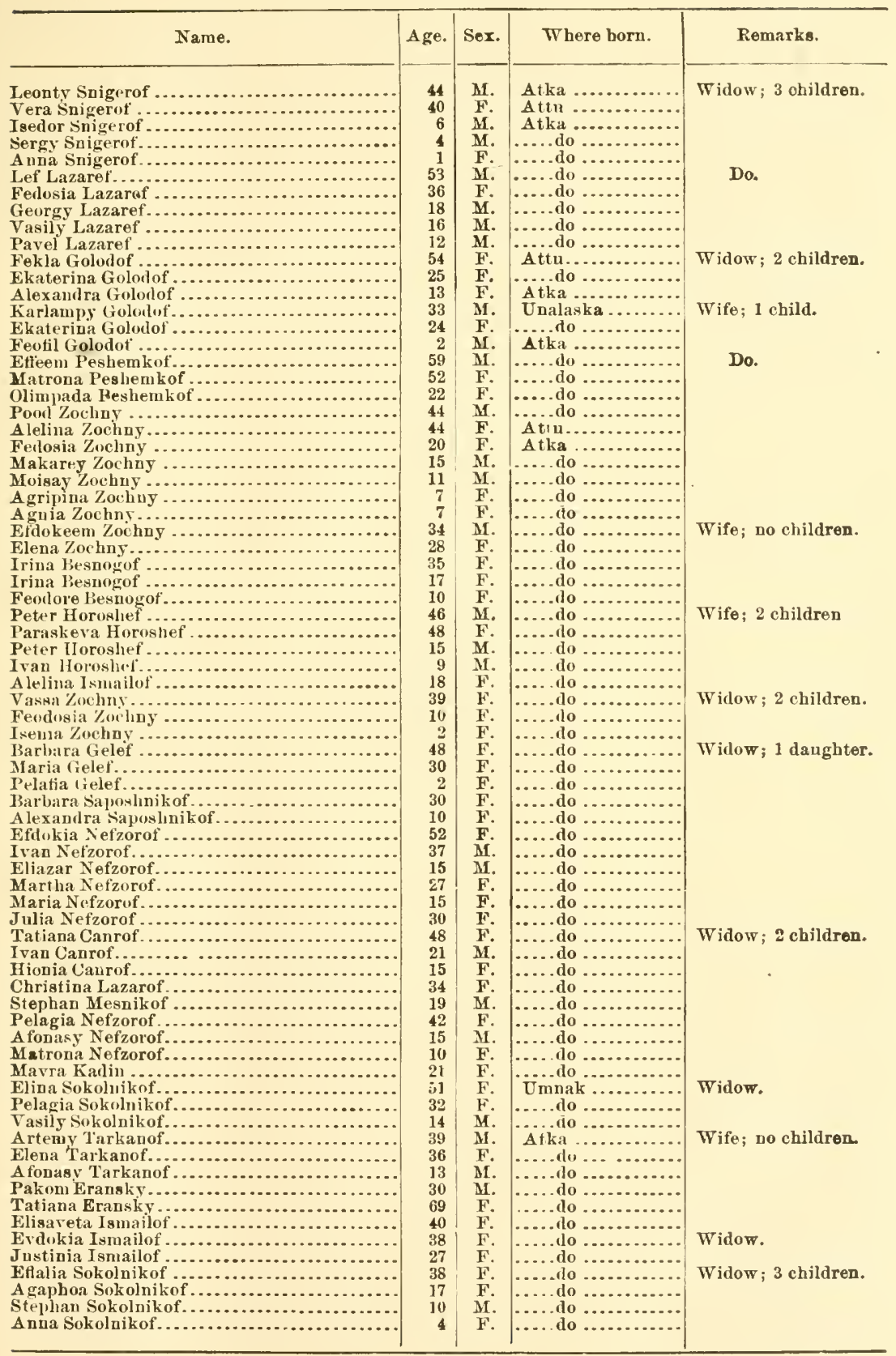


Census of Attu Island.

\begin{tabular}{|c|c|c|c|c|}
\hline 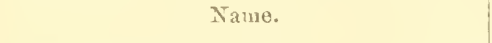 & A ge. & Sex. & Where born. & Remarks. \\
\hline 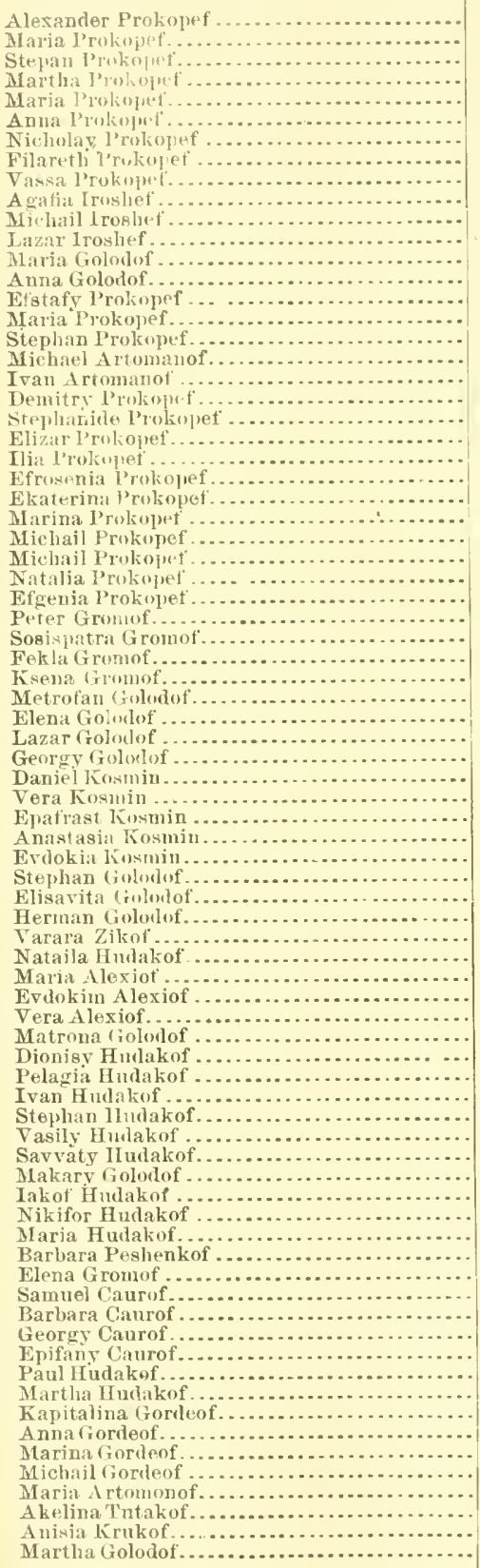 & 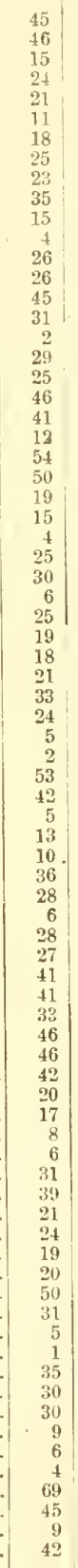 & 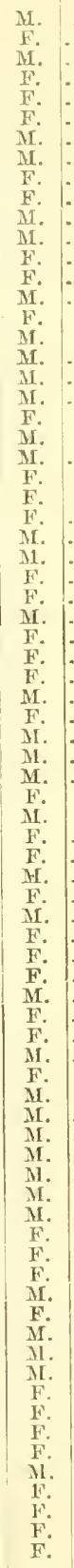 & 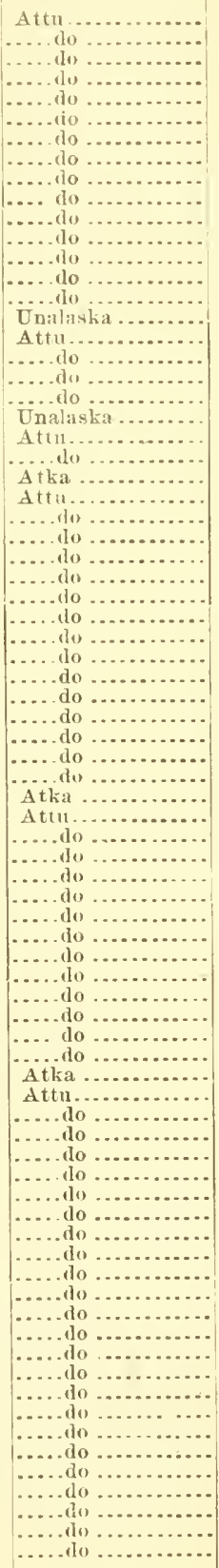 & $\begin{array}{l}\text { Widow; } 2 \text { children. } \\
\text { Widow; } 1 \text { child. } \\
\text { Wife; } 1 \text { child. } \\
\text { Do. } \\
\text { Wife; } 3 \text { children. } \\
\text { Wife; } 1 \text { child. } \\
\text { Wife; no children. } \\
\text { Wife; } 2 \text { children. }\end{array}$ \\
\hline
\end{tabular}




\section{RECAPITULATION.}

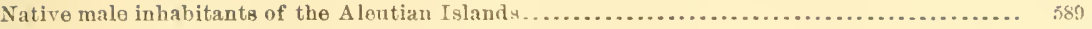

Native female inhabitants of the Aleutian Islands . . . . . . . . . . . . . . . . . . . . . . . . . . . . . . . 576

Total native inhabitants of the Aleutian Islands...........................

Clergy and iumates of Jessio Lee Home, Unalaska, not emmerated or incluched in number of native inhalitints:

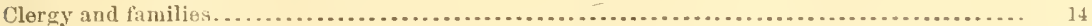

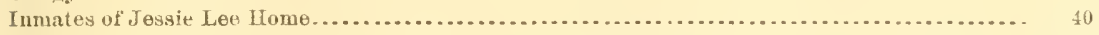

Total

The settlement of Korovinski, on Korovin Island, contains abont 30 inhabitants. An iccurate census was not obtained.

The native inhabitants of st. P'aul, Kodiak, who are nearly all sea-otter hunters, are not included in the toregoing. 



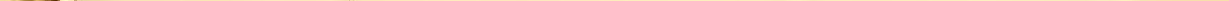








LIBRARY OF CONGRESS

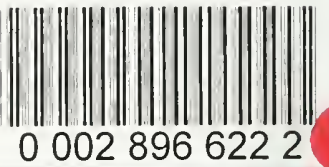

